Article

\title{
The Potential Role of Direct Air Capture in the German Energy Research Program-Results of a Multi-Dimensional Analysis
}

\author{
Peter Viebahn *(D), Alexander Scholz and Ole Zelt ${ }^{(\mathbb{D}}$ \\ Wuppertal Institute for Climate, Environment and Energy, Doeppersberg 19, 42103 Wuppertal, Germany \\ * Correspondence: peter.viebahn@wupperinst.org; Tel.: +49-202-2492-306
}

Received: 11 August 2019; Accepted: 2 September 2019; Published: 6 September 2019

\begin{abstract}
A significant reduction in greenhouse gas emissions will be necessary in the coming decades to enable the global community to avoid the most dangerous consequences of man-made global warming. This fact is reflected in Germany's 7th Federal Energy Research Program (EFP), which was adopted in 2018. Direct Air Capture (DAC) technologies used to absorb carbon dioxide $\left(\mathrm{CO}_{2}\right)$ from the atmosphere comprise one way to achieve these reductions in greenhouse gases. DAC has been identified as a technology (group) for which there are still major technology gaps. The intention of this article is to explore the potential role of DAC for the EFP by using a multi-dimensional analysis showing the technology's possible contributions to the German government's energy and climate policy goals and to German industry's global reputation in the field of modern energy technologies, as well as the possibilities of integrating DAC into the existing energy system. The results show that the future role of DAC is affected by a variety of uncertainty factors. The technology is still in an early stage of development and has yet to prove its large-scale technical feasibility, as well as its economic viability. The results of the multi-dimensional evaluation, as well as the need for further technological development, integrated assessment, and systems-level analyses, justify the inclusion of DAC technology in national energy research programs like the EFP.
\end{abstract}

Keywords: Direct Air Capture; DAC; sector coupling; negative emission technologies; carbon dioxide removal; Power-to- $X$; energy transition; climate change

\section{Introduction}

A significant reduction in greenhouse gas emissions will be necessary in the coming decades to enable the global community to avoid the most dangerous consequences of man-made global warming. In particular, this means keeping the global temperature rise well below two degrees Celsius above pre-industrial levels [1]. In the Paris Agreement of the 21st United Nations Conference of the Parties (COP 21) in 2015, the international community agreed to make efforts to limit the rise in temperature to 1.5 degrees Celsius by 2100 [2]. Such a restrictive goal requires a comprehensive and, above all, rapid transformation in almost all sectors, with a substantial reduction in greenhouse gas emissions by 2030, i.e., within just over ten years [3].

Such ambitious goals can only be achieved with a mix of different technologies. A number of these technologies are known today. Many of them have already been developed for the most part and are ready for the market. Others can achieve market penetration if general conditions in the energy industry are suitable. Furthermore, there are a few core requirements for the further development of technologies, for the provision of complementary technologies (e.g., grids and storage facilities) that enable market introduction or penetration, and for the narrowing of technology gaps. 
These ideas are reflected in Germany's 7th Federal Energy Research Program (EFP), entitled "Innovations for the Energy Transition" and adopted in 2018 [4]. In the 40 years of its existence, the EFP has been repeatedly adapted to new societal challenges. To prepare for the 7th EFP, the "Technologies for the Energy Transition" research project [5] analyzed a large number of technologies with regard to their development status, their potential for growth, and their possible research needs. To do so, the project carried out a systematic comparative multi-dimensional analysis. It assessed these technologies with regard to their abilities to meet the requirements of the energy industry, as well as climate policy, their capacity to help leading German companies continue to expand, and their likelihood of securing technological options by promoting technology on a broad front. The analysis employed a total of 12 different criteria (see Figure 1). Due to the nature of the requirements for this analysis, the criteria were neither quantified nor weighted, and the different technologies were not ranked.

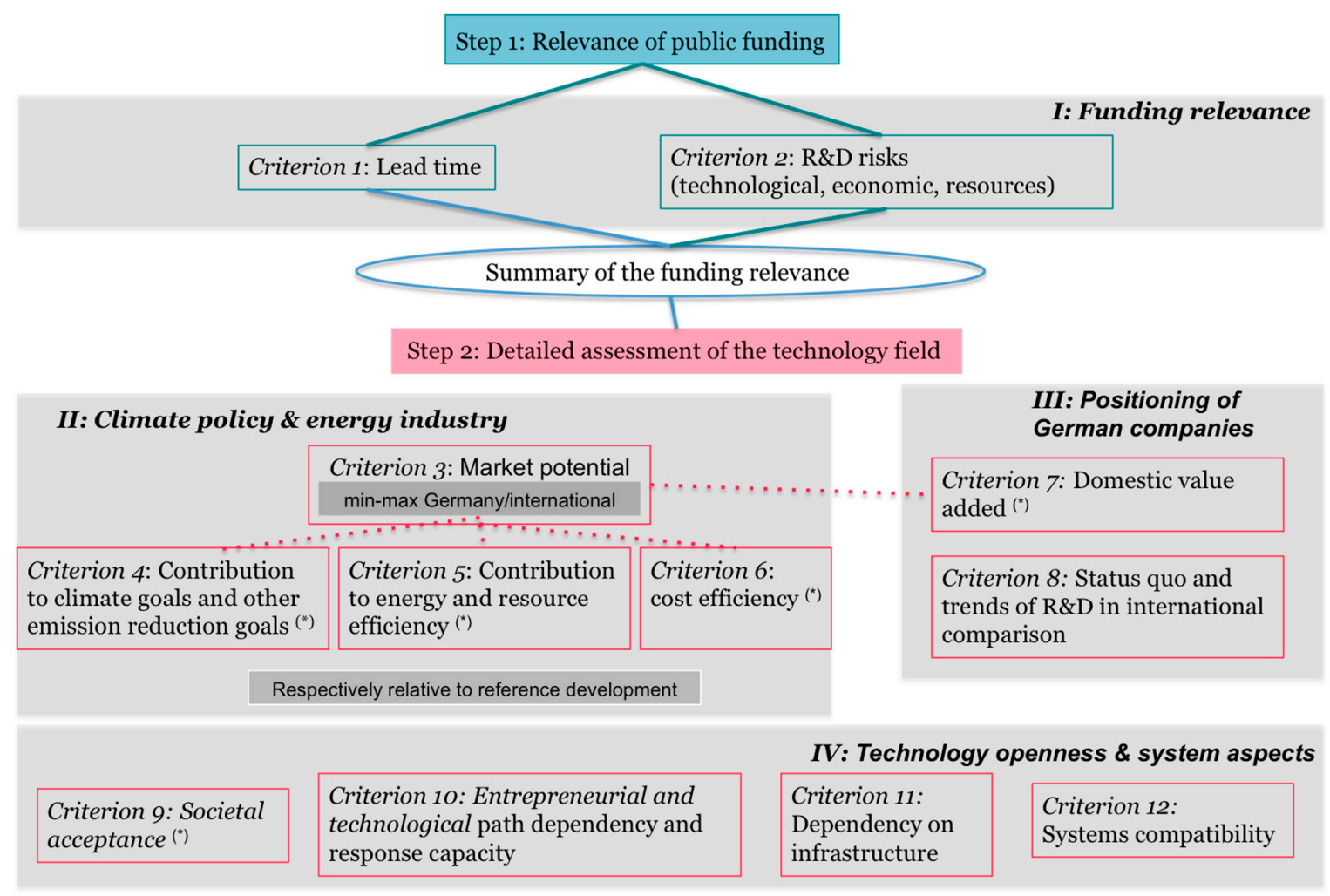

Figure 1. General multi-dimensional analysis framework; criteria that could only partly be applied in the case of Direct Air Capture (DAC) are marked with $\left(^{*}\right)$.

Direct Air Capture (DAC), sometimes also known as Direct Air Carbon Capture (DACC), was identified as one of the technologies for which there was still a large technology gap. In contrast to $\mathrm{CO}_{2}$ capture from power plants or industrial processes that target large point sources, DAC technologies are capable of directly capturing carbon dioxide from ambient air and thus from distributed sources. The use of such systems is theoretically conceivable at any location worldwide, and thus also offers regions without concentrated $\mathrm{CO}_{2}$ sources the potential to contribute to capturing $\mathrm{CO}_{2}$. However, this also presumes that the demand for electricity or heat-depending on the DAC process-is met by renewable sources, and that sufficient space is available. In addition, some processes require considerable amounts of water.

DAC could make a significant contribution to achieving the objective of reducing greenhouse gas (GHG) emissions through two primary applications. First, by providing climate-neutral carbon dioxide for synthesis processes, DAC could function as an enabler for the production of electricity-based fuels (Power-to-Liquids (PtL)), gases (Power-to-Gas (PtG)), and chemicals (Power-to-Chemicals (PtC)). 
Second, DAC could act as a Negative Emission Technology (NET), by capturing large amounts of carbon dioxide from the atmosphere in combination with subsequent long-term geological storage (Direct Air Carbon Capture and Storage (DACCS)). On the one hand, if determined and purposeful action is taken and a massive reduction of energy consumption through the implementation of various energy efficiency measures is achieved, it may be possible to meet the climate targets without NET [6-8]. On the other hand, the majority of the Intergovernmental Panel on Climate Change (IPCC) scenarios see the use of NETs as unavoidable to achieve the $2{ }^{\circ} \mathrm{C}$ target, and especially the $1.5^{\circ} \mathrm{C}$ target $[1,3]$. Their use cannot be limited to a single technology, but all NETs have their own role and potential $[9,10]$. Since both technology options are still largely ignored in energy policy, and the use of NETs has not yet been widely discussed in public, DAC was included in the multi-dimensional analysis.

To the authors' knowledge, no analysis with a comparable comprehensive scope has been published before, either in general or with a focus on German energy research needs. When assessments of DAC systems have been carried out, this has been done in two ways. First, techno-economic assessment studies have evaluated future technical development (for example, the energy and water needs, the efficiency, or process specifications), combined with economic calculations (such as the potential $\mathrm{CO}_{2}$ savings costs or the levelized cost of captured $\mathrm{CO}_{2}$ ). The most comprehensive of such evaluations was published by Fasihi et al. after completing the recommendations for the EFP [11]. The authors reviewed all known DAC technologies, estimated their possible technical development until 2050, and conducted a dynamic cost analysis using the learning curve method in order to compare the different technology options in the long run. In addition, they briefly discussed the land use needs and water consumption of DAC.

Second, assessments of DAC potential have been conducted within integrated assessment models (IAM). One group of climate scientists assessed the global $\mathrm{CO}_{2}$ removal potential, cost, and relevant side effects of DAC and other NETs on a global level by way of a refereed literature review $[9,10,12]$. However, this analysis neither considered the implementation level as intended in this article, nor did it result in a multi-dimensional analysis. Before that, Smith et al. had compared different requirements and impacts of NETs on a global level (land use, water, and energy demand and cost) [13].

Against this background, the intention of this article is to explore the possible role of DAC for the German Energy Research Program by means of a multi-dimensional analysis and to show the research needs that DAC still demands. Where possible, the results of the reference study [5] are updated with regard to studies published afterwards.

The remainder of the article is organized as follows: Section 2 describes the methodologies applied in the multi-dimensional analysis and gives a rough overview on the status of DAC; the outcome of each analysis step is given in Section 3; and after discussing the results from an integrative perspective in Section 4, some final conclusions are drawn in Section 5.

\section{Processes and Methods}

\subsection{DAC Technologies and Their Applications}

DAC procedures usually consist of three steps [14]. First, the ambient air must be directed to the sorbent in a suitable manner ("contacting"). This can be accelerated by fans, for example, but normal drafts can also be used [15]. Second, the $\mathrm{CO}_{2}$ from the ambient air must be bound by absorbing or adsorbing substances, for which aqueous solutions or solids are used. In the last step, the $\mathrm{CO}_{2}$ is separated from the sorbent, usually by supplying thermal or electrical energy. After this phase of regeneration, the sorbent is ready again for a new cycle in its original form. Approaches to gas separation generally differ with regard to the choice of sorbent and the type of regeneration. In general, gas separation can be performed by physical or chemical processes:

- Physical absorption in liquid media: These can be organic compounds that require little effort for regeneration, but a high pressure for absorption. They are used, for example, in the removal of sulfur compounds and $\mathrm{CO}_{2}$ from natural gas, but are not suitable for low concentrations, such as 
those present in the air with $\mathrm{CO}_{2}$. Inorganic compounds such as sodium hydroxide $(\mathrm{NaOH})$ or potassium hydroxide $(\mathrm{KOH})$ can be used as alternatives suitable for a low pressure. However, they require high temperature heat or electrodialysis for regeneration;

- Adsorption on solid media: Since the binding energy of liquid media is so strong that regeneration requires a considerable amount of energy, these processes usually rely on solids [14,15]. Since solids that adsorb physically are not suitable for low concentrations of the gas to be absorbed, in the case of DAC, chemical adsorption is applied. Examples are the use of solid (poly)amines directly as sorbents or the use of (poly)amines chemically bound to solids. The $\mathrm{CO}_{2}$ is then mainly regenerated by low-temperature heat (temperature swing adsorption, TSA), often in combination with pressure swing adsorption (PSA) or moisture (humidity swing adsorption).

The following three concepts summarize the most relevant processes, as outlined by scientific literature and industry. They are classified according to their thermal energy demand, which itself depends on their particular binding mechanisms according to the concepts outlined above. While the early concepts were designed purely on the basis of the use of electricity, the focus has shifted to heat-based processes. Table A1. gives an overview of existing or planned demonstration facilities.

- "DAC $\mathrm{C}_{\mathrm{n} T \mathrm{~T} p}$ ": Absorption and electrodialysis (use of dissolved inorganic compounds);

- "DAC $\mathrm{CighTemp}_{\text {": }}$ Absorption and calcination (use of dissolved inorganic compounds);

- "DAC $C_{\text {lowTemp }}$ ": Adsorption and desorption (binding to solids).

\subsubsection{Solution-Based Absorption and Electrodialysis ("DAC noTemp")}

Around 20 years ago, Specht et al. from the Centre for Solar Energy and Hydrogen Research Baden-Württemberg (ZSW) in Germany developed a process in which air is drawn in and the $\mathrm{CO}_{2}$ contained in it is absorbed using an $\mathrm{NaOH}$ solution [16]. By acidifying the resulting sodium carbonate solution $\left(\mathrm{Na}_{2} \mathrm{CO}_{3}\right)$ with sulfuric acid $\left(\mathrm{H}_{2} \mathrm{SO}_{4}\right)$, the $\mathrm{CO}_{2}$ is separated again in an almost pure form. This is followed by restoration of the $\mathrm{NaOH}$ and sulfuric acid via an electrochemically driven membrane process in which substances can be separated from solvents using bipolar membranes (electrodialysis). The processes described by Eisaman et al. at the Palo Alto Research Center (PARC) also followed this scheme, although in this case, a total of six different mixtures of potassium hydrogen carbonate $\left(\mathrm{KHCO}_{3}\right)$, potassium carbonate $\left(\mathrm{K}_{2} \mathrm{CO}_{3}\right)$, and $\mathrm{KOH}$ solutions were tested as absorbents [17]. The subsequent recovery was carried out by electrodialysis. Both processes require only electricity, and no thermal energy. 2009 the ZSW process was redesigned for continuous operation eliminating the use of sulfuric acid. The necessary acidification of the $\mathrm{Na}_{2} \mathrm{CO}_{3}$ solution was made directly in an electrodialysis cell. Nevertheless, there was no commercial application.

\subsubsection{Solution-Based Absorption and Calcination ("DAC $C_{\text {highTemp") }}$}

In this process, $\mathrm{CO}_{2}$ is absorbed in a similar way to the previous process, using $\mathrm{NaOH}$ or $\mathrm{KOH}$ as an aqueous solution. Baciocchi et al. proposed a $\mathrm{NaOH}$-based process [18], which the American Physical Society (APS) has used as a reference system for its technology assessment [19] and which was optimized by Mazotti et al. [20] and Zeman [21]. A Canadian company, Carbon Engineering, on the other hand, uses $\mathrm{KOH}$. The aqueous potassium carbonate $\left(\mathrm{K}_{2} \mathrm{CO}_{3}\right)$ resulting from $\mathrm{CO}_{2}$ absorption is precipitated into calcium carbonate $\left(\mathrm{CaCO}_{3}\right)$ in a pellet reactor and decomposed into $\mathrm{CO}_{2}$ and calcium oxide $(\mathrm{CaO})$ by calcination. The latter is hydrated to calcium hydroxide $\left(\mathrm{Ca}(\mathrm{OH})_{2}\right)$ and is then available for further processing [22]. The calcination requires very high temperatures $\left(>850{ }^{\circ} \mathrm{C}\right)$, which Carbon Engineering achieves by using natural gas firing in its current demonstration plant in Squamish (Canada), absorbing $0.6 \mathrm{t} \mathrm{CO}_{2} /$ day from the air (= $219 \mathrm{t} \mathrm{CO}_{2} /$ year). The company uses the separated $\mathrm{CO}_{2}$ for the production of synthetic fuels. In extensive and comprehensively documented model calculations and techno-economic analyses, the process was recently up-scaled to a commercially usable absorption size of $1 \mathrm{Mt} \mathrm{CO}_{2} /$ year [23]. 
In Carbon Engineering's natural gas-based approach, every ton of $\mathrm{CO}_{2}$ captured from the atmosphere, however, releases $0.48 \mathrm{t}$ of fossil $\mathrm{CO}_{2}$, which is only partly captured by an additional integrated post-combustion process [23]. Assuming a "renewable-based world" with a simultaneous need for negative emissions, this concept might be obsolete. Instead, electricity-based gas (P2G) could be used, but its production would be very energy-intensive [11]. Alternatively, it would be conceivable to use concentrated solar power (CSP) plants that would generate high-temperature heat. This would be an option if solar-thermally produced hydrogen and separated $\mathrm{CO}_{2}$ were to be further processed into synthesis products at the same time and in the same place, as has been recently demonstrated in a project in Spain [24]. To the authors' knowledge, no corresponding studies are yet available.

\subsubsection{Solid-Based Adsorption and Desorption ("DAC lowTemp")}

One company, Climeworks AG, uses amine compounds that are bonded to dry porous granulates as filter material in connection with the use of air moisture. Once the material is fully enriched with $\mathrm{CO}_{2}$, the adsorbent is regenerated applying a combination of vacuum (PSA) and temperature swing (TSA) in the low-temperature range (approx. $100{ }^{\circ} \mathrm{C}$ ) and delivers $\mathrm{CO}_{2}$ at a purity of $99.9 \%$. [25,26]. Since mainly low temperatures are required here (in contrast to the process described above), the thermal energy requirement is significantly lower and allows the integration of waste heat from electrolyzers, industrial plants, or synthesizing plants (e.g., methanization or the production of synfuels, syngas, or synchemicals). In addition to thermal energy, small amounts of electricity are required for the blower. A further advantage of this process is that the moisture contained in the air is available as water after it has passed through the process, and can thus be used for other processes, e.g., electrolysis as a basis for the production of synfuels. Climeworks offers a standard module, the "DAC-1" (0.14 $\mathrm{t} \mathrm{CO}_{2} /$ day), which can be combined into larger units as desired (e.g., a "DAC-36" with 36 units, yielding $2.46 \mathrm{t} \mathrm{CO}_{2} /$ day $=900 \mathrm{t} /$ year) $[25,26]$.

Climeworks operates demonstration projects in Zurich, Rapperswil, and Hinwil (Switzerland). In Hellisheiði, Iceland, the $\mathrm{CO}_{2}$ is mixed with water for long-term sequestration and discharged as carbonic acid into $700 \mathrm{~m}$ deep basalt rocks, where it combines with the minerals magnesium, calcium, and iron present there. Due to the high temperatures in the basalt (approx. $400^{\circ} \mathrm{C}$ ), carbonate formation occurs within two years, after which the $\mathrm{CO}_{2}$ remains permanently stored, as the EU research project CarbFix successfully demonstrated [27]. This plant is thus the first DACCS project in the world, and the firm now also sells $\mathrm{CO}_{2}$ certificates commercially for offsetting emissions [28]. Additional plants are being tested in European research projects for the purpose of PtG and PtC. On a commercial basis, the Norwegian Heroya project has set out the aim to produce 8000 tons of "Blue Crude" annually from 2020 onwards [29], and 292 tons of kerosene will be produced annually from 2020 onwards [30] at the airport in Rotterdam, the Netherlands.

The US company Global Thermostat is also working with the principles of adsorption and desorption. It uses porous, honeycomb ceramic "monoliths" as filter material on the surface of which amine compounds are deposited. The adsorbent is regenerated using low-temperature steam $\left(85-100{ }^{\circ} \mathrm{C}\right)(\mathrm{TSA})$ and delivers $\mathrm{CO}_{2}$ at a purity of $98 \%$ [31]. It is currently operating a pilot plant in California ( $2 \mathrm{t} \mathrm{CO}_{2} /$ day) and running six commercial projects in various industries. The company is planning to offer DAC modules with a $\mathrm{CO}_{2}$ absorption capacity of up to $2 \mathrm{Mt} / \mathrm{year}$ by combining base modules (50 kt/year) into larger plants similar to Climeworks. The company has also signaled their intention to capture $\mathrm{CO}_{2}$ from neighboring fossil-fired power plants and simultaneously decouple the required heat [31].

As part of the Finnish SOLETAIR research project, the VTT Technology Research Centre and Lappeenranta University developed a compact synthetic fuel plant that produced its first 200 liters of fuel in 2017 [32-34]. An integrated DAC plant ( $3.8 \mathrm{~kg} \mathrm{CO}_{2} /$ day $=1.39 \mathrm{t} /$ year), developed by Hydrocell, a Finnish fuel cell producer [35], also operates according to the adsorption/desorption process, but uses a resin with polymeric amines attached as the solid ("amine-functionalized polystyrene spherical beads"). Both the $\mathrm{CO}_{2}$ and the water are adsorbed on the amines and, after saturation of the adsorbent, are 
recovered in a vacuum, with heat input provided by a fuel cell. The plant is designed for the production of $80 \mathrm{l} /$ day (= $22 \mathrm{t} /$ year) gasoline. The long-term goal of the project is to produce aromatic hydrocarbons such as benzene, toluene, and xylene as the basis for current-based polymers (e.g., polyurethane).

Lackner at Arizona State University's Center for Negative Emission has also described a solids-based adsorption process; his project uses an ion exchange resin, and desorption takes place by means of a humidity swing (moistening the $\mathrm{CO}_{2}$-rich sorbent) [15]. The energy requirement is a very low $50 \mathrm{~kJ} / \mathrm{mol} \mathrm{CO}_{2}(0.32 \mathrm{MWh} / \mathrm{t} \mathrm{CO})$ due to working with $45^{\circ} \mathrm{C}$ instead of $100{ }^{\circ} \mathrm{C}$ heat. However, the process has so far been limited to theoretical conceptualization and laboratory-scale prototypes. In contrast to highly pure $\mathrm{CO}_{2}$, this process delivers " $\mathrm{CO}_{2}$-enriched air" [36].

Another low-temperature process within this technology group has recently been demonstrated by Germany's ZSW in the course of the CORAL project (" $\mathrm{CO}_{2}$ Raw Material from Air"). This newly developed capture process for the reversible absorption of carbon dioxide is based on an aqueous solution of high molecular branched polyethyleneimine (PEI) [37]. Regeneration also takes place by low-temperature heat. As further development, ZSW envisages the adsorptive parallel production of water and $\mathrm{CO}_{2}$ as renewable raw materials for electrolysis and synthesis based on solid bound PEI.

\subsection{Multi-Dimensional Analysis}

This paper pursues a multi-dimensional approach covering 12 evaluation criteria, with each criterion investigated using specific methods. Unless otherwise stated, the analysis is mainly qualitatively performed by a literature review, expert interviews, and the authors' expert knowledge, in an effort to provide an overview of the technology's status and to determine research and development (R\&D) needs. For the multi-dimensional analysis, the reference study [5] developed a general analysis framework (Figure 1). It described a collection of criteria that should help to explore the possible contribution of the technologies assessed here to the goals of the German EFP. Since DAC is a fairly new technology with only a few installations globally, not all criteria could be fully applied, as described below.

In contrast to the procedure applied with a conventional multi-criteria assessment (MCA), which usually contains numerical quantification of the individual criteria and mutual correlations of them, the approach outlined here does not quantify and weight each of the criteria, nor does it rank the different technologies. Due to the novelty of the considered technologies, the available data is too uncertain or not complete enough to make a substantiated comparison. In some cases, it is also not possible to differentiate between the sub-technologies of DAC. Instead, the aim of the analysis given here is to show how DAC or its sub-technologies contribute to the respective objectives of the EFP and for which criteria no or only limited statements are possible.

\subsubsection{Step 1}

The first step required using two criteria to assess whether the conditions for public research funding were met; such criteria are subject to strict conditions. The need for targeted government support for R\&D has been particularly justified by market shortcomings and industrial policy considerations [38]. "Market shortcomings" in the energy sector concern the problems of long-time horizons of energy technology developments from invention to commercial use, some of which lie far beyond the usual business planning and calculation deadlines; the high and often incalculable technological and economic risks of R\&D, which cannot be covered by the market; and the strategic importance of energy for the economy, the environment, and society. For reasons of industrial policy, technological developments require pioneers who, in many cases, are often dependent on support from R\&D funding. Market leadership can only be achieved with an appropriate technological lead.

\section{Criterion 1: Lead Time}

This criterion serves as an indicator for estimating the time until the first large-scale commercial DAC plant would be in operation, ranging from 2020 to after 2050. A plant is considered "commercial" 
if its Technology Readiness Level (TRL) (see below) has a score of 9, which means it is obtainable on the market and competitive (i.e., there are sufficient market incentives). Private investors tend to avoid projects with long lead times, and those long lead times are thus an important reason for funding.

\section{Criterion 2: R\&D Risks}

This criterion is split into two sub-criteria. First, the particular DAC technology's stage of development is assessed by using the internationally approved concept of the Technology Readiness Level, which divides R\&D into steps from invention to market along a scale of 1 to 9 . For the classification of TRL, guidelines developed by Project Management Jülich are applied [39]. This sub-criteria is followed by an evaluation of technological and economic R\&D risks. Here, only technology-specific factors are considered, precluding exogenous risks, such as the general price development of primary energy sources. The verification of sufficient R\&D risks is mandatory for public research funding.

\subsubsection{Step 2}

If both criteria justify public research funding, Step 2 evaluates whether and how much they contribute to the goals of German research funding.

Criteria 3-6 evaluate possible contributions to meeting the German government's energy and climate policy targets. This gives priority to areas and technologies that contribute to improving energy efficiency to a desired extent and to underwriting the expansion of renewable energies in such a way that the specified market shares of renewable energies can be achieved. The task of this funding policy is, in particular, to make these technologies more cost-effective and therefore pave the way for rapid market penetration, while at the same time taking compatibility with the environment and nature into account.

\section{Criterion 3: Market Potential}

This criterion helps to estimate the future global and national demand for DAC systems, serving as a basis for Criterion 7 (Domestic added value). However, there are a variety of uncertain development paths for this technology, mainly due to the existence of different use cases with specific implications, as well as competing $\mathrm{CO}_{2}$ sources (e.g., industrial or biomass), whose temporal availability and utilization ratios are unclear. Since only a few scenarios incorporating those uncertainties have been published, the market potential is analyzed in terms of $\mathrm{CO}_{2}$ captured from the air that may be needed nationally and globally, both for facilitating Power-to-X $(\mathrm{PtX})$ processes and for achieving net negative emissions. Regarding the first application, carbon-neutral fuels and chemicals are considered as an example. It is not the goal to develop detailed and complete scenarios based on an integrated energy model. Rather, for the analysis pursued here, a rough estimate will have to suffice to gauge the magnitude to which DAC technologies could be in demand on the market in the future.

Regarding the use of carbon-neutral fuel and chemical production, the given calculations are based on possible development for PtL and PtC demand, as stated by Arnold et al. [40] (both on a German and global scale). This meant adopting the following key assumptions:

- Estimates for the German PtL demand are based on [41], which, to the authors' knowledge, is the only scenario study that has examined the possible demand for synthetic fuels for transport at the German level. PtL is considered in the most far-reaching scenario in [41], "KS95", the "Climate Protection Scenario". This scenario sets out the goal of a 95\% reduction in greenhouse gases by 2050 in Germany. It hypothesizes a significant demand for electricity-based fuels, with 75 TWh in 2040 and 95 TWh in 2050, adopted for the conversion of heavy load and air traffic. Assuming ideal conversion, carbon mass fractions would suggest that the mass of the $\mathrm{CO}_{2}$ required would be 3.14 times the mass of the fuel produced (expressed in simplified terms as $\mathrm{C}_{n} \mathrm{H}_{2 n}$ );

- Regarding global PtL production, almost no scenario shows a demand for synthetic fuels. The only scenario that explicitly identifies synthetic fuels is the "Advanced Energy [R]evolution" scenario [6], 
representing a $1.5^{\circ} \mathrm{C}$ scenario. It implies a slow increase of PtL production by 2020 (19 TWh) and vigorous growth from 2030 (130 TWh) until 2050 (1496 TWh). In relative terms, however, such fuels would play only a minor role, as the scenario assumes considerable savings in transport service on the one hand, and a massive shift to biofuels, electric vehicles, and hydrogen on the other. Even more than the German scenario, the global scenario therefore deliberately represents a lower limit of demand for synthetic fuels;

- Regarding German PtC production, it is assumed that, in the long term, the entire basic materials industry and thus also the entire chemical industry will have to become independent of sources from fossil raw materials. The total demand for petrochemicals can be expressed in ethylene equivalents and roughly corresponds to three times the ethylene demand. This demand is met by migration to renewable methanol, with subsequent Methanol-to-Olefin MTO) or Oxidative Coupling of Methane (OCM) paths. Applying the above estimate to ethylene $\left(\mathrm{CH}_{2}\right)$, the mass of carbon dioxide required is calculated to be 3.14 times the mass of ethylene produced. In line with the aforementioned "KS95" Climate Protection Scenario, our model assumes that 95\% of petrochemicals will be produced in this way in 2050 (following $20 \%$ migration of conventional chemical production to $\mathrm{PtC}$ in 2030 and $60 \%$ in 2040);

- When estimating global PtC production, the same technical assumptions apply. Furthermore, a steady increase of global ethylene and other hydrocarbons' demand is assumed, starting with $600 \mathrm{Mt}$ ethylene equivalents in 2020 and reaching $1430 \mathrm{Mt}$ by 2050 (based on hydrocarbon development expectations [42-44]). To cap the maximum temperature increase at $1.5^{\circ} \mathrm{C}$, the International Energy Agency (IEA) has indicated that the world must achieve net zero emissions between 2040 and 2060 [45]. Accordingly, our model assumes an almost complete substitution (95\%) of fossil raw materials of the petrochemical industry by the year 2050, with a gradual transition from $10 \%$ in 2030 and $50 \%$ in 2040.

In summary, the PtL scenarios represent sustainability scenarios with considerable efficiency gains and thus a lower limit for future consumption, while the $\mathrm{PtC}$ scenarios are more of a reference scenario, without demand constraints and thus a higher upper limit. For all cases considered, this study assumes that the required $\mathrm{CO}_{2}$ is provided through DAC. Since the scenarios used are in line with the $1.5^{\circ} \mathrm{C}$ target, the use of climate-neutral $\mathrm{CO}_{2}$ is essential, although fossil $\mathrm{CO}_{2}$ from industry could also be used in the first few years while building up DAC production facilities.

As a second field of application, DAC could play a role as NET. On the one hand, the use of the other main technology under consideration so far, biomass and carbon capture and storage (BECCS) and consequently biomass cultivation, cannot be expanded at will for various reasons (land consumption, issues concerning competition with agriculture for food, etc.) [46,47]. On the other hand, no single NET will be able to meet the large deployment of NETs needed if the $1.5^{\circ} \mathrm{C}$ target is to be achieved [9]. Accordingly, considerable amounts of DAC are ascribed to the period 2060-2100 by Chen and Tavoni [48] (referring to the $2{ }^{\circ} \mathrm{C}$ target), and by Marcucci et al. ([49], referring to the $1.5^{\circ} \mathrm{C}$ target), as a result of integrated assessment models and applying the $\mathrm{DAC}_{\text {highTemp }}$ technology described in [19]. Both papers assume increasing $\mathrm{CO}_{2}$ emissions in order to maximize welfare until 2050, and in doing so, accept temporary temperature overshoot. As a result, after 2060, significant quantities of NET - up to $35 \mathrm{Gt} \mathrm{CO}_{2} /$ year-will need to be covered by DAC, which will also offset emissions from distributed sources (transport, heating systems). In addition, CCS is assumed for the combustion of fossil and biomass-based power plants. In view of the extreme assumptions of the underlying modeling, these quantities may represent the upper limit for the use of DAC. Other climate scientists have hypothesized a necessity to use NET technologies as early as 2020 to avoid temperature overshoot; in this way, Rogelj et al. calculated a lower annual use of DAC-up to $20 \mathrm{Gt}^{C_{2}}$ /year in 2100-but also not limited to one technology [50]. In order to map a lower limit, it is assumed that $50 \%$ of this may be achieved through DAC. In accordance with Germany's share of $\mathrm{CO}_{2}$ emissions (730 Mt in 2015) compared to global $\mathrm{CO}_{2}$ emissions (32.3 Gt in 2015), it is further assumed that $2.25 \%$ 
of global NET obligations may be borne by Germany. In relation to the above figures, this would result in 225-787 $\mathrm{Mt} \mathrm{CO}_{2}$ that would have to be removed from the atmosphere by DAC in Germany.

\section{Criterion 4: Contribution to Climate Goals and Other Emission Reduction Goals}

Within the general analysis framework of the reference study [5], this criterion serves to determine the possible contribution of a given technology to GHG reduction goals by comparing it with the use of a fossil reference technology. However, since DAC serves both as a facilitator for other GHG reduction technologies and as a way to achieve negative emissions itself, there is no reference system to compare it with. Therefore, this criterion is not applicable to DAC. Instead, in the cases of PtL and PtC, references correspond to the GHG reduction contribution that PtL and PtC could achieve by switching to electricity-based processes from renewable energies in Germany, as stated in reference [40].

\section{Criterion 5: Contribution to Energy and Resource Efficiency}

Similar to Criterion 4, there is no reference system for DAC to compare energy and resource consumption with. Instead, the demands for energy, land, and water resources are derived for various DAC systems, and are then compared with each other in order to illustrate the current status of such technologies and possible long-term developments.

\section{Criterion 6: Cost Efficiency}

Similar to the previous criteria, there is no reference system to compare cost with. Again, current and future costs of various DAC processes are estimated and compared.

Criteria 7 and 8 serve to evaluate whether a technology is suitable for expanding the already leading position of German companies in the field of modern energy technologies. The targeted orientation of energy research and technology policy toward global development should open up new opportunities to not only complement the German government's international climate protection policy, but also support growth and employment policy in Germany.

\section{Criterion 7: Domestic Value Added}

This criterion serves as an indicator for the domestic economic relevance of the technology. It indicates the contribution that the national and international expansion of the technology under consideration could make to German value creation. In order to determine the possible production volume or the resulting value, the market potential determined in Criterion 3 should be weighted in light of the possible global market share of German companies. In order to determine this global market share, it is necessary, for example, to question whether the technical competence for the development and use of the technology is available at research institutions and in companies in Germany; whether production capacities exist; or whether there are research partnerships for the technology at the national level, or with significant German participation internationally. After using this to calculate the market potential for German companies, it is then possible to calculate the actual contributions made by companies based in Germany.

\section{Criterion 8: Status Quo and Trends of R\&D in International Comparison}

This criterion is used to determine how DAC in Germany is positioned on the industrial side in comparison with other countries, and how its R\&D landscape differs from that of other countries, applying four different sub-criteria. This means first qualitatively evaluating the international positioning of the German economy and determining the development of public R\&D budgets and research results (scientific publications and patents) in an international comparison. Secondly, a patent analysis is conducted via three search engines (DPMAregister, Espacenet, and Google Patents), with different combinations of the search terms " $\mathrm{CO}_{2}$ Abtrennung aus der Luft", "Direct Air Capture", "DAC", and "Air Capture". Finally, a literature mining is performed by applying the search query 
[(direct W/0 air W/0 capture) OR (direct W/0 air W/0 carbon) OR (capture W/0 from W/0 air) OR (dac AND (energy OR climate) AND ("NET" OR (negative W/0 emission W/0 technology)))] to all articles contained in the Scopus database up to July 2019.

Criteria 9-12 take into account overarching, systemic aspects. They are used to evaluate whether and under what conditions a technology can also be integrated into the existing energy system and accepted by society.

\section{Criterion 9: Societal Acceptance}

This criterion measures the public acceptance of DAC at the local level, as well as within the German economy and society at large. It thus helps decision-makers assess the extent to which support or objection can be expected in the event of further expansion, so that the need for supplemental measures can be identified in the case of particularly controversial technologies. Wüstenhagen et al. have argued that three different levels of observation can be used to recognize acceptance distributions in a society [51]. "Socio-Political Acceptance" measures the overall social climate vis-à-vis a given technology. In contrast, "Community Acceptance" captures local perceptions and reactions, and can heavily influence planning and decision-making processes. "Market acceptance", on the other hand, looks at it from the perspective of investors and consumers and, for example, provides specifics about the current diffusion of a (new) technology.

\section{Criterion 10: Entrepreneurial and Technological Path Dependency and Response Capacity}

This criterion represents the extent to which the use of DAC may affect structures in the energy supply in the short, medium, or long term. On the one hand, this means assessing the economically useful life of a given technology and thereby assessing future structural change; on the other hand, it is necessary to estimate investment depending on timelines for technical planning, construction, and commissioning.

\section{Criterion 11: Dependence on Infrastructure}

This criterion serves as an indicator for whether market penetration of DAC would depend on either existing energy-related infrastructure (such as power lines, district heating grids, or $\mathrm{CO}_{2}$ pipelines), or whether it must be constructed. More general aspects like roads, waterways, or railroads are not included in the analysis, since every technology requires a minimum of transportation infrastructure.

\section{Criterion 12: Systems Compatibility}

This criterion serves as an indicator for how compatible DAC would be with the energy system and climate policy in general. It estimates how large the feedback effects and interactions of DAC use would be and what effort would have to be made to adapt the systems interacting with the investigated technology. In this way, the assessment should ensure that risks and tradeoffs stemming from the technology or the corresponding system are identified and can be considered from an overall perspective. Measuring compatibility requires the sub-criteria of reactions, adaptation requirements, and interactions to be examined.

\section{Results}

\subsection{Criterion 1: Lead Time}

Mainly for financial reasons, existing facilities are still far from large-scale implementation, and will probably rely on market incentive programs to mature into competitive products. Therefore, under conservative assumptions, it seems unlikely that DAC will be commercially available on a large-scale before 2030. In a recent MIT Technology Review, Bill Gates ranked DAC as one of ten breakthrough technologies that would have (commercial) availability in five to ten years [52]. This has been indirectly confirmed by manufacturers who advertise their systems as essentially market-ready 
(i.e., TRL of 9), but who would need R\&D programs to reduce their costs from the current $\$ 600 / \mathrm{t} C \mathrm{O}_{2}$ to a more competitive $\$ 100 / \mathrm{t} \mathrm{CO}{ }_{2}$ within the next ten years [25,53]. Technical learning through $\mathrm{R} \& \mathrm{D}$ support would complement cost reduction through volume effects and economies of scale.

\subsection{Criterion 2: RED Risks}

\subsubsection{Stage of Development}

As depicted in Table 1, TRL indications differ significantly, depending on the literature sources and the given technological concept. According to Napp et al., all NETs, including DAC (but excluding BECCS), are at a very early development stage, with TRLs of 1-3 [54]. Other studies differentiate among different sorbents, and assign TRLs of 3-5 to hydroxide solutions, which are used for $\mathrm{DAC}_{\text {noTemp }}$ and $\mathrm{DAC}_{\text {highTemp, }}$, while assigning TRLs of 2-4 to amine-based $\mathrm{DAC}_{\text {lowTemp }}$ systems [55]. Some more

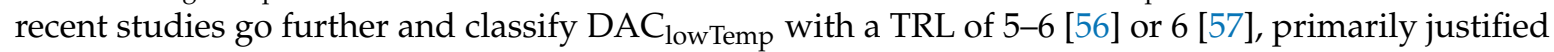
by the existence of several prototypes far exceeding lab-scale application. Accordingly, Climeworks ranks its own DAC lowTemp technology at TRL 9, given current costs [25].

Table 1. Current development stages of Direct Air Capture (DAC) according to their Technology Readiness Level (TRL) (own composition, based on [25,54-57]; boxes are ticked for all TRLs given in the different sources analyzed).

\begin{tabular}{|c|c|c|c|c|}
\hline $\begin{array}{l}\text { Overarching } \\
\text { Classification }\end{array}$ & Detailed Classification & $\mathrm{DAC}_{\text {noTemp }}$ & DAC $_{\text {highTemp }}$ & DAC $_{\text {lowTemp }}$ \\
\hline \multicolumn{5}{|c|}{ Basic research } \\
\hline TRL 1 & $\begin{array}{l}\text { Basic principles observed and described, } \\
\text { potential applications conceivable }\end{array}$ & $\bigotimes$ & $\bigotimes$ & $\bigotimes$ \\
\hline \multicolumn{5}{|c|}{ Technology development } \\
\hline TRL 2 & $\begin{array}{c}\text { Description of a technological concept } \\
\text { and/or application }\end{array}$ & $\bigotimes$ & $\bigotimes$ & $\bigotimes$ \\
\hline TRL 3 & $\begin{array}{l}\text { Basic functional verification of individual } \\
\text { elements of an application/technology }\end{array}$ & $\bigotimes$ & $\bigotimes$ & $\bigotimes$ \\
\hline TRL 4 & $\begin{array}{l}\text { Basic proof of function, } \\
\text { technology/application in the laboratory }\end{array}$ & $\bigotimes$ & $\bigotimes$ & $\bigotimes$ \\
\hline \multicolumn{5}{|c|}{ Demonstration } \\
\hline TRL 5 & $\begin{array}{l}\text { Functional verification in an } \\
\text { application-relevant environment }\end{array}$ & $\bigotimes$ & $\bigotimes$ & $\bigotimes$ \\
\hline TRL 6 & $\begin{array}{l}\text { Verification using a demonstrator in an } \\
\text { application-relevant environment }\end{array}$ & & & \\
\hline TRL 7 & Prototype test in an operating environment & & & \\
\hline TRL 8 & $\begin{array}{l}\text { Qualified system with proof of } \\
\text { functionality in an operating environment }\end{array}$ & & & \\
\hline \multicolumn{5}{|c|}{ Commercialization } \\
\hline TRL 9 & Successful commercial system deployment & L & $\square$ & $\bigotimes$ \\
\hline
\end{tabular}

Boxes are ticked, if at least one of the analyzed sources identified the corresponding TRL level for the technology groups.

\subsubsection{Technical and Economic R\&D Risks}

As depicted in Table 2, technical risk is assumed to be rather low, because between Climeworks and Global Thermostat, two of the three larger companies under review have already begun offering their technologies on the market. The third large company, Carbon Engineering, has tried to limit its technical risks by aligning the design of its large-scale process with the availability of commercial hardware [22]. Economic R\&D risk is perceived as being high in general, since measures that induce 
cost reductions, such as technical learning, upscaling, and mass production, all depend on adequate sales markets; these will only emerge under appropriate carbon control mechanisms. Even more contingencies arise in cases of using DAC within synthesis processes. On the one hand, the cost of $\mathrm{CO}_{2}$ capture is only one cost component among several. On the other hand, these processes themselves are reliant on market incentive programs.

Table 2. Assessment of technical and economic research and development (R\&D) risks for Direct Air Capture (DAC) (own estimation).

\begin{tabular}{|c|c|c|c|c|c|c|}
\hline Type of Risk & Very Low & Low & Rather Low & Rather High & High & Very High \\
\hline $\begin{array}{l}\text { The technical research } \\
\text { and development risk is } \\
\text { The economic research } \\
\text { and development risk is }\end{array}$ & & & $\bigotimes$ & & 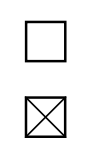 & $\square$ \\
\hline
\end{tabular}

Ticked boxes show the level of the risk.

The results of both criteria justify the inclusion of DAC in the energy research program. In particular, technical learning stimulated by R\&D funding would significantly reduce the lead times and economic risk.

\subsection{Criterion 3: Market Potential}

Table 3 shows the scenario results for a possible carbon-neutral $\mathrm{CO}_{2}$ demand caused by PtL and PtC production, both in Germany and globally, according to the assumptions set out in the definition of the criterion. In the case of Germany, an almost complete substitution of conventional chemical production by $\mathrm{PtC}$ would result in a $\mathrm{CO}_{2}$ demand of $55 \mathrm{Mt} \mathrm{CO}_{2}$ /year by 2050, which is approximately twice as much as that needed for PtL (however, transportation is mainly covered by other decarbonization strategies in the assumed scenario, which makes this assessment rather conservative).

Table 3. German and global $\mathrm{CO}_{2}$ demand for carbon-neutral production of Power-to-Liquids (PtL) and Power-to-Chemicals (PtC) by 2050 in $\mathrm{Mt} \mathrm{CO}_{2} /$ year.

\begin{tabular}{ccccc}
\hline Mt CO & /year & \multicolumn{2}{c}{ Germany } & \multicolumn{2}{c}{ Global } \\
\hline Year & PtL & PtC & PtL & PtC \\
\hline Scenario & $\begin{array}{c}\text { Heavy load, } \\
\text { aviation }\end{array}$ & $\begin{array}{c}\text { Ethylene } \\
\text { equivalents }\end{array}$ & $\begin{array}{c}\text { Road, rail, navigation, } \\
\text { aviation }\end{array}$ & $\begin{array}{c}\text { Ethylene } \\
\text { equivalents }\end{array}$ \\
\hline 2020 & 0 & 0 & 5 & 0 \\
2030 & 0 & 11 & 35 & 333 \\
2040 & 20 & 35 & 203 & 2043 \\
2050 & 26 & 55 & 403 & 4274 \\
\hline
\end{tabular}

An almost complete worldwide substitution of (increasing) conventional chemical production by $\mathrm{PtC}$ would result in a $\mathrm{CO}_{2}$ demand of $4500 \mathrm{Mt} \mathrm{CO}_{2}$ /year by 2050. These figures are approximately 100 times higher than those in the German scenario and are determined by vigorous growth in demand, especially in China, India, and the U.S. According to the scenario assumption in the traffic sector, $\mathrm{PtL}$ production would result in a relatively small demand of $400 \mathrm{Mt} \mathrm{CO}_{2} /$ year in 2050 .

The second aspect to consider is the necessary effort to globally achieve negative emissions. As Figure 2 illustrates, the global demand for DAC, as modeled by Chen and Tavoni [48] and Marcucci et al. [49], far exceeds those quantities required by $\mathrm{PtL}$ and $\mathrm{PtC}$, which are assumed to remain constant from 2050 onwards. In comparison, the more moderate global demand derived from Rogelj et al. [50], by assuming that $50 \%$ of the stated negative emissions may be achieved by DAC, is in the same order of magnitude as the demand for PtC. Figure 3 shows the proportion of $\mathrm{CO}_{2}$ required 
for negative emissions for which Germany might be responsible, in comparison to the demand of $80 \mathrm{Mt} /$ year that is required by PtL and PtC domestically.

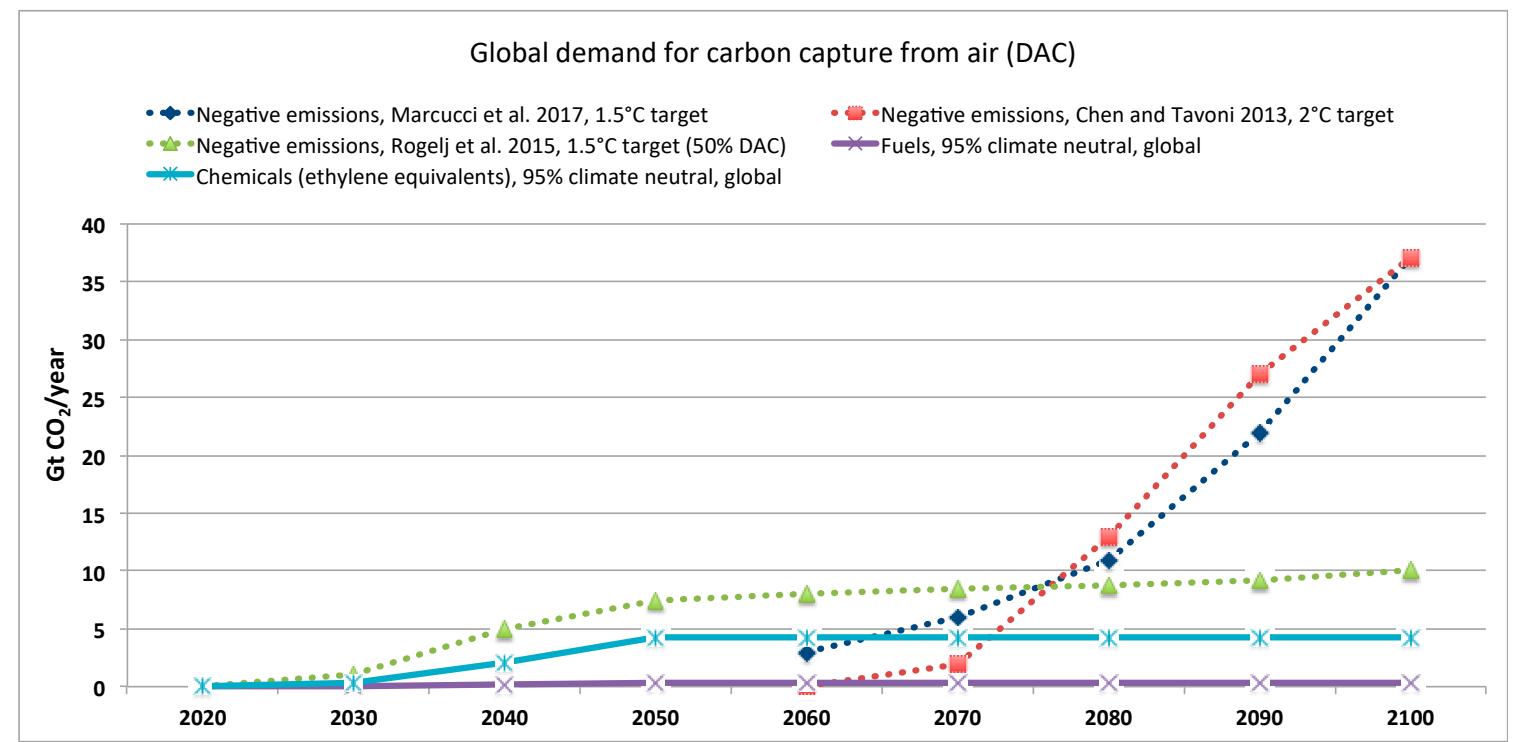

Figure 2. Global Direct Air Capture (DAC) demand for achieving negative emissions from 2060 in comparison with globally required climate-neutral $\mathrm{CO}_{2}$ for Power-to-Liquids (PtL) and Power-to-Chemicals (PtC) in $\mathrm{Gt} \mathrm{CO}_{2} /$ year.

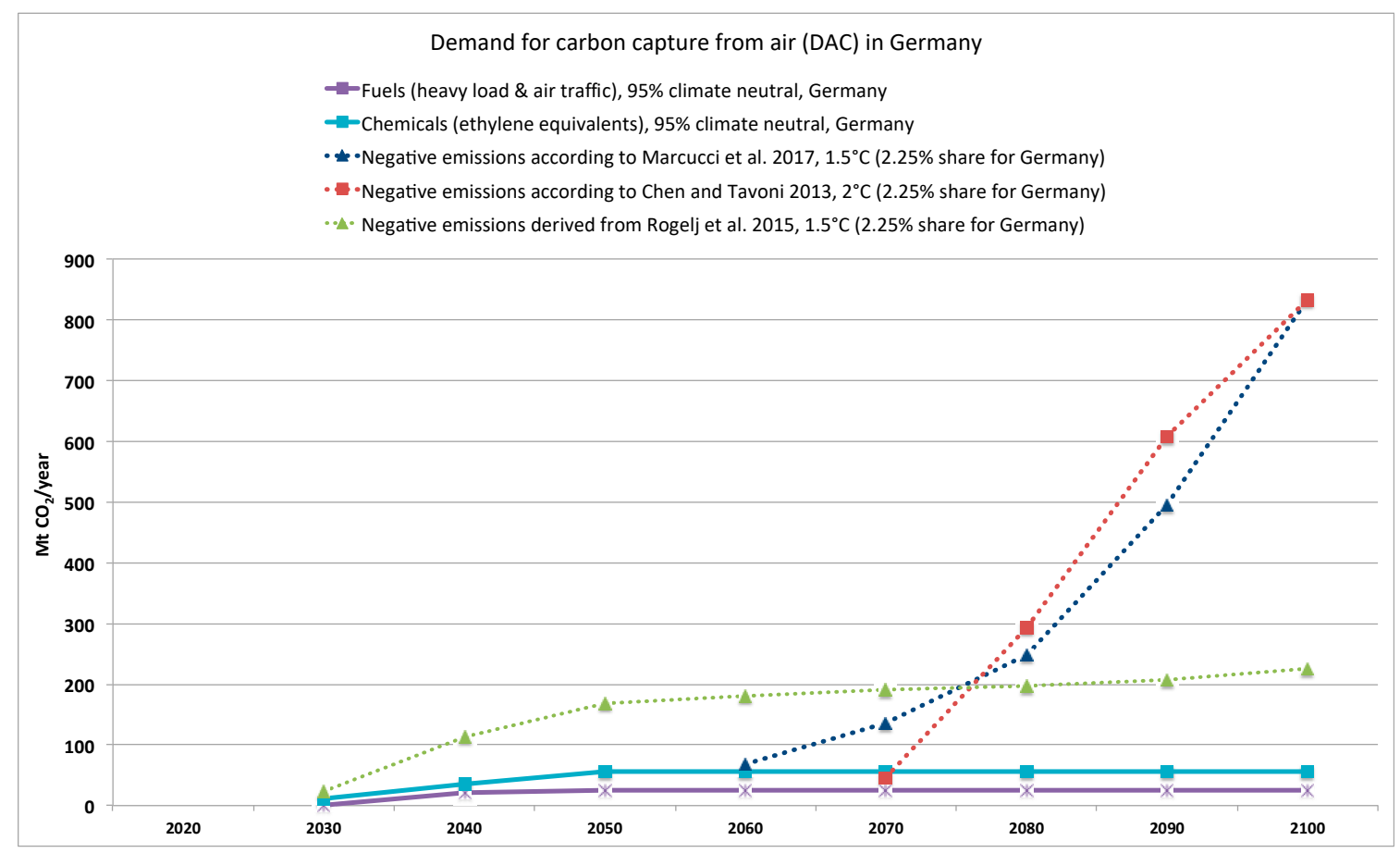

Figure 3. German demand for Direct Air Capture (DAC) for negative emissions according to Germany's share of global $\mathrm{CO}_{2}$ emissions (dotted lines), compared to the German demand for carbon neutral $\mathrm{CO}_{2}$ for Power-to-Liquids (PtL) and Power-to-Chemicals (PtC) (solid lines) in $\mathrm{Mt} \mathrm{CO}_{2} /$ year. 


\subsection{Criterion 5: Contribution to Energy and Resource Efficiency (Energy, Land, and Water Demand)}

\subsubsection{Energy Demand}

In theory, the capture of $\mathrm{CO}_{2}$ by DAC would require two to four times as much energy as the capture of exhaust gases from a power plant [14,19], which is relatively low in view of a 250-300 times lower concentration of $\mathrm{CO}_{2}$ in the air. On the other hand, ideal consumption in reality is often considerably exceeded, so that much worse values can be expected than in the case of CCS. APS has stated $0.124 \mathrm{MWh} / \mathrm{t} \mathrm{CO}_{2}$ as the thermodynamic minimum required to capture $50 \%$ of the $\mathrm{CO}_{2}$ present in the ambient air at a concentration of $500 \mathrm{ppm}$, supplemented by $0.06 \mathrm{MWh} / \mathrm{t} \mathrm{CO}_{2}$ for $\mathrm{CO}_{2}$ compression [19]. In practice, however, these minimum values are never reached.

Table 4 depicts specific energy-related parameters of the various types of DAC processes. The figures are not directly comparable because they were determined for specific system configurations. Nevertheless, they show that future large-scale commercial plants can still be expected to deliver significant energy savings. Lackner's process has by far the lowest energy requirement, but is still only a theoretical concept. Compared to Carbon Engineering's system, the Climeworks system can cover its heat requirement from waste heat due to the low temperature level, which makes it predisposed for use in PtX processes. The same is true for the newly developed system from ZSW, while no data is available for Global Thermostat. Overall, it is evident that development from initially power-intensive $\left(\mathrm{DAC}_{\text {noTemp }}\right)$ to thermal (DAC $\left.\mathrm{DhhTemp}_{\text {and }} \mathrm{DAC}_{\text {lowTemp }}\right)$ processes has occurred.

Table 4. Specific energy consumption of various types of Direct Air Capture (DAC) processes.

\begin{tabular}{|c|c|c|c|c|c|c|c|c|}
\hline \multirow[t]{2}{*}{$\begin{array}{l}\text { Energy Sources, } \\
\text { Specifications }\end{array}$} & \multirow[t]{2}{*}{ Unit } & \multicolumn{2}{|c|}{ DAC $_{\text {noTemp }}$} & \multirow{2}{*}{$\frac{\text { DAC }_{\text {highTemp }}}{\text { Carbon Engineering }^{5)}}$} & \multicolumn{4}{|c|}{ DAC $_{\text {lowTemp }}$} \\
\hline & & ZSW & PARC & & Clime-works & Lackner 6) & $\begin{array}{c}\text { Global } \\
\text { Thermostat }\end{array}$ & ZSW \\
\hline Sources & & [16] & [17] & {$[25,58]$} & {$[25,53]$} & [15] & [31] & [37] \\
\hline Natural gas & $\begin{array}{c}\mathrm{MWh}_{\mathrm{th}} / \mathrm{t} \\
\mathrm{CO}_{2}\end{array}$ & - & - & $2.78^{1)} \rightarrow 1.46-2.45^{2-4)}$ & - & - & n.a. & - \\
\hline (Low-temp) heat & $\begin{array}{c}\mathrm{MWh}_{\mathrm{th}} / \mathrm{t} \\
\mathrm{CO}_{2}\end{array}$ & - & - & 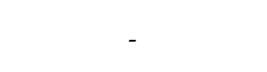 & $2.5 \rightarrow 1.5^{2)}$ & 0.32 & n.a. & $2-2.5$ \\
\hline Electricity & $\begin{array}{c}\mathrm{MWh}_{\mathrm{el}} / \mathrm{t} \\
\mathrm{CO}_{2}\end{array}$ & 2.72 & 1.89 & $\begin{array}{c}0 \rightarrow 0-0.366^{2)} \text { 3) 4) } \\
\left.\quad 0-0.077^{2)} 4\right)\end{array}$ & 0.5 & n.a. & n.a. & $0.5-1$ \\
\hline $\begin{array}{c}\text { Temperature for } \\
\mathrm{CO}_{2} \text { capture }\end{array}$ & ${ }^{\circ} \mathrm{C}$ & n.a. & n.a. & $>850$ & 100 & 45 & 85-100 & 110 \\
\hline Purity of $\mathrm{CO}_{2}$ & & $>99$ & $>99$ & n.a. & 99.9 & n.a. & 98 & 99.9 \\
\hline
\end{tabular}

\subsubsection{Land Use}

Table 5 summarizes the land use parameters of the various DAC processes (no data is available for $\left.\mathrm{DAC}_{\text {noTemp }}\right)$. The figures regarding system dimensions vary by several magnitudes. According to APS,

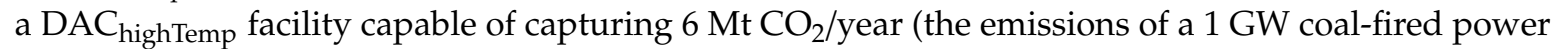
plant) would require approximately $9 \mathrm{~km}^{2}$, i.e., $1.5 \mathrm{~km}^{2} /\left(\mathrm{Mt} \mathrm{CO}_{2} \cdot\right.$ year) [19]. Since this figure does not include any area set aside for energy generation facilities [13], high-temperature heat delivering plants, such as natural gas or concentrated solar power plants (the latter including large areas for concentrating tubes or mirrors) must be accounted for. Carbon Engineering has indicated dimensions of $8 \mathrm{~m} \times 200 \mathrm{~m}$ for capturing $0.1 \mathrm{Mt} \mathrm{CO}_{2} /$ year, i.e., $0.0016 \mathrm{~km}^{2} /\left(\mathrm{Mt} \mathrm{CO}_{2}\right.$.year). However, the company itself uses those dimensions only to refer to the packings, and concedes that actual land use would be significantly higher [59]. 
Table 5. Specific land use of the various types of Direct Air Capture (DAC) processes (not including the area set aside for energy generation facilities).

\begin{tabular}{|c|c|c|c|c|c|c|c|}
\hline \multirow[t]{2}{*}{ Parameters } & \multirow[t]{2}{*}{ Unit } & \multicolumn{2}{|c|}{ DAC $_{\text {highTemp }}$} & \multicolumn{4}{|c|}{ DAC $_{\text {lowTemp }}$} \\
\hline & & APS & $\begin{array}{c}\text { Carbon } \\
\text { Engineering }{ }^{2)}\end{array}$ & Clime-Works & Clime-Works & Lackner & $\begin{array}{c}\text { Global } \\
\text { Thermostat }\end{array}$ \\
\hline Sources & & [19] & [59] & \multicolumn{2}{|c|}{$[25,26]$} & [15] & {$[31]$} \\
\hline Total & $\mathrm{km}^{2}$ & 9 & $>0.0016$ & 0.00009 & & $3 \times 10^{-5}$ & \\
\hline $\begin{array}{l}\text { Reference } \\
\text { value }\end{array}$ & $\mathrm{Mt} \mathrm{CO}_{2} /$ year & 6 & 0.1 & 0.0009 & & $3.65 \times 10^{-4}$ & \\
\hline Specific & $\begin{array}{c}\mathrm{km}^{2} /(\mathrm{Mt} \\
\left.\mathrm{CO}_{2} \cdot \text { year }\right) \\
\end{array}$ & 1.5 & $>0.016$ & 0.1 & $2^{1)}$ & 0.08 & $0.05-0.002$ \\
\hline
\end{tabular}

${ }^{1)}$ Including area set aside for heat supply by photovoltaic-powered heat pumps. ${ }^{2)}$ Only packings - actual land use

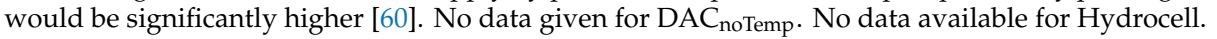

In the case of DAC lowTemp, Climeworks has stated that it only requires $90 \mathrm{~m}^{2}$ for a DAC-18 type system, which would be capable of capturing $0.9 \mathrm{kt} \mathrm{CO}_{2} /$ year, i.e., resulting in an area of $0.1 \mathrm{~km}^{2} /\left(\mathrm{Mt} \mathrm{CO}_{2} \cdot\right.$ year$)$, mainly consisting of clearance between facilities [25,26]. Again, energy generation plants have been excluded from these figures. If they couple their system with synthesis plants, only the necessary electricity demand would have to be taken into account, since waste heat would be available. In the case of DACCS, accounting for additional heat supply is relevant since waste heat delivery facilities would not necessarily be available. If, for example, photovoltaic-operated heat pumps were used, the necessary area would increase to approximately $2 \mathrm{~km}^{2} /\left(\mathrm{MtCO}_{2}\right.$, a) at optimal sites [25,26]. Lackner states $30 \mathrm{~m}^{2}$ for capturing $365 \mathrm{t} \mathrm{CO}_{2} /$ year, i.e., $0.08 \mathrm{~km}^{2} /\left(\mathrm{MtCO}_{2} \cdot\right.$ year $)$ [15]. Global Thermostat has indicated $20-500 \mathrm{t} \mathrm{CO}_{2} /\left(\mathrm{a} \cdot \mathrm{m}^{2}\right)$, which is $0.05-0.002 \mathrm{~km}^{2} /\left(\mathrm{Mt} \mathrm{CO}_{2} \cdot\right.$ year) [31].

\subsubsection{Water Demand}

In their comparison of various NETs for DAC, Smith et al. calculated a water consumption of 19.9-30 $\mathrm{m}^{3} / \mathrm{t} \mathrm{CO}_{2}$ for DAC [13]. The range of values is not comprehensible, since their Supplementary Information referred to amine solutions on the one hand, and the referenced source says nothing

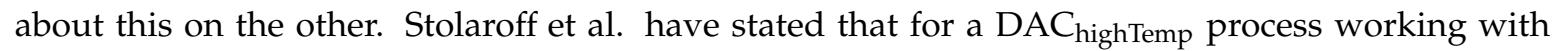
aqueous $\mathrm{NaOH}$ solutions, water losses due to evaporation would be $20 \mathrm{~mol} \mathrm{H}_{2} \mathrm{O} / \mathrm{mol} \mathrm{CO}_{2}$ for a certain parameter setting [60], which would thus correspond to $8.18 \mathrm{~m}^{3} / \mathrm{t} \mathrm{CO}_{2}$. Even if these values could be reduced by process improvements, significant water losses would have to be expected. Carbon Engineering has declared a net water consumption of $4.7 \mathrm{~m}^{3} / \mathrm{t} \mathrm{CO}$ for its aqueous $\mathrm{KOH}$ solution pilot plant. This ratio fluctuates with temperature, ambient conditions, and solution molarity [23].

Climeworks, on the other hand, produces approximately $1 \mathrm{~m}^{3}$ water $/ \mathrm{t} \mathrm{CO}_{2}$, since the TSA process does not consume any water, while, at the same time, the vapor taken in with the ambient air can be used $[25,26]$. In this way, the Climeworks system can capture $\mathrm{CO}_{2}$ at a single location, produce hydrogen from the water obtained, and generate synthetic products from syngas, while the waste heat is in turn used for air capture. The first such cogeneration project has already been successfully demonstrated for the production of kerosene (using solar thermochemical water splitting via CSP instead of electrolysis) [24]. No figures were available for Global Thermostat.

\subsection{Criterion 6: Costs}

Table 6 depicts both current and estimated future costs of the various types of DAC processes, as stated by the manufacturers. Carbon Engineering recently reported a fall in cost expectations from $\$ 600 / \mathrm{t} \mathrm{CO}_{2}$ to a (levelized) $\$ 94-\$ 130 / \mathrm{t} \mathrm{CO}_{2}$ for providing $\mathrm{CO}_{2}$ for fuel synthesis and to $\$ 113-\$ 232 / \mathrm{t}$ $\mathrm{CO}_{2}$ including compression of the $\mathrm{CO}_{2}$ to $15 \mathrm{MPa}$ for storage. In so doing, they considered various forecasts of future electricity prices ( $\$ 30-\$ 60 / \mathrm{MWh}$ ) and a natural gas price of $\$ 12.6 / \mathrm{MWh}$, but omitted the assumed cost of water [23]. It should be noted that their work refers to a conceptual design, modeled with Aspen, which has not yet been built. Climeworks has stated costs of $\$ 600 / \mathrm{t} \mathrm{CO}_{2}$ 
for actual operation and has aimed to reach $\$ 200 / t \mathrm{CO}_{2}$ by 2020 as a result of upscaling and mass production, and $\$ 100 / \mathrm{t} \mathrm{CO}$ by $2025-2030$ as a result of further $\mathrm{R} \& \mathrm{D}$, in each case without mentioning the underlying energy prices [25,53]. Global Thermostat has even asserted costs of only $\$ 50 / \mathrm{t} \mathrm{CO}_{2}[53]$, which seems fairly unrealistic, given the lack of data and detailed explanations. Further cost reductions depend on how long the amine surfaces last [61]. Lackner's design had the same cost targets, but it is in a very early development stage. No cost data was given for the ZSW's newly developed process [37].

Table 6. Costs of various types of Direct Air Capture (DAC) processes.

\begin{tabular}{cccccc}
\hline Time Period & Unit & DAC $_{\text {highTemp }}$ & \multicolumn{3}{c}{ DAC $_{\text {lowTemp }}$} \\
\hline & & Carbon Engineering & Climeworks & Lackner & $\begin{array}{c}\text { Global } \\
\text { Thermostat }\end{array}$ \\
\hline Sources & & {$[23]$} & {$[25]$} & {$[15]$} & {$[53,61]$} \\
\hline Present & $\$ / \mathrm{CO}_{2}$ & 600 & 600 & 220 & $501)$ \\
Prognosis & $\$ / \mathrm{tCO}_{2}$ & $94-130(0.1 \mathrm{MPa})^{1)}$ & $200(2020) 100$ & 25 & $15-50$ \\
\hline
\end{tabular}

\footnotetext{
1) Cost assumed for the "Nth plant". ${ }^{2)}$ To be used for subsequent storage, and therefore not comparable with other figures. No data given for $\mathrm{DAC}_{\mathrm{no}}$ Temp. No data available for Hydrocell.
}

Older cost statements in scientific literature spanned even more widely, ranging from $\$ 25 / \mathrm{t} \mathrm{CO}_{2}$ to $\$ 1000 / \mathrm{tCO}_{2}$. However, both upper and lower bounds referred to either very early or vague assessments (see, e.g., [21,62]). No data was available for the early electricity-based processes developed by ZSW and PARC. Furthermore, none of the papers assessed used learning rates to estimate future cost developments. The only models that considered endogenous learning were climate models exploring DAC as NET between 2060 and 2100, each without specifying the corresponding learning rates [48,49]. Climeworks cited learning rates of $20 \%$ according to their cost forecasts [25], which seems high but not unrealistic, given similar developments of other low-carbon technologies [63].

Since this study was prepared in an effort to assess the need for DAC's inclusion in a research program, standardizing the specific company data and making rigorous estimates of future costs were outside the scope of this paper. After completion of the study, a comprehensive techno-economic evaluation was published [11] in which the authors calculated the levelized cost of DAC (LCOD). The cost figures projected for 2050 resulted in $\$ 60-\$ 79 / \mathrm{tCO}_{2}$ for $\mathrm{DAC}_{\text {highTemp }}$ and $\$ 42-\$ 60 / \mathrm{t} \mathrm{CO}_{2}$ for $\mathrm{DAC}_{\text {lowTemp }}$ (using a conversion factor of $€ 0.90 / \$ 1$ as of July 2019) (each without compression of $\mathrm{CO}_{2}$ ). It depended on various general conditions and learning rates, as well as electricity costs of $\$ 55.6 / \mathrm{MWh}$, low-temperature heat $\left(<100{ }^{\circ} \mathrm{C}\right)$, costs of $\$ 22.2 / \mathrm{MWh}$, and high-temperature heat $\left(900{ }^{\circ} \mathrm{C}\right)$ costs of $\$ 27.8 / \mathrm{MWh}$. These figures show that, depending on the assumptions made about scenarios and parameters, the vague figures supplied by companies could fall even further in the long term.

\subsection{Criterion 7 (Domestic Value Added)}

Currently, no calculations according to the criteria description are possible, as there is no German company developing DAC processes. As described above, the research center ZSW has developed its own DAC lowTerm process. In addition, Climeworks and its German subsidiary are involved in various research projects in Germany. Additional research work might also be underway at universities. Nevertheless, if one considers the strong position of the German chemical industry and the mechanical engineering industry, it can be assumed that German companies would also enter a DAC market as soon as the demand for the provision of climate-neutral $\mathrm{CO}_{2}$ for $\mathrm{PtX}$ applications becomes more specific. In the foreseeable future, however, $\mathrm{CO}_{2}$ from industrial plants will probably be used for this purpose. During this time, corresponding production capacities for DAC could be developed. The discussion on negative emissions has so far only been conducted among climate scientists and, due to the long-term nature of its implementation, is unlikely to be the focus of industry for the time being. Even without the ability to calculate the specific contribution to value added, the market potential to be 
expected estimated in Figure 3 justifies the inclusion of DAC in the German energy research program solely on the basis of German demand.

\subsection{Criterion 8 (Status-Quo and Trends of RED in International Comparison)}

Currently, there are no known German manufacturers of DAC technologies. To the authors' knowledge, the public R\&D budget has only been made available for two research projects, each by the Federal Ministry of Education and Research: The CORAL Project (" $\mathrm{CO}_{2}$ Raw Material from Air") received funding with a duration of 2016-2019 (the resulting process, from ZSW, was one of the aforementioned $\mathrm{DAC}_{\text {lowTemp }}$ systems). Within the ongoing "Power-to-X" Copernicus project, the "A2: Low Temperature Co-Electrolysis" research cluster is developing an integrated plant for the production of liquid fuels. A number of additional research activities, e.g., on absorption processes, are likely to be supported by R\&D funding, but cannot be directly attributed to the development of DAC plants.

Regarding the research output, the patent search yielded no results for Germany. Worldwide, 20 patent applications have been filed: four each in the USA and Canada, two in China, and one each in Croatia and Mexico (as of March 2018). In addition, three European (EP) and three World Intellectual Property Organization (WIPO) patents were identified.

Finally, the publication analysis revealed 290 refereed papers from 2006 to July 2019; of these, papers that contained no direct reference to DAC, or where the main focus was clearly not on DAC (e.g., in the case of other meanings of DAC, such as "diamond-anvil cell" in medicine; other meanings of "air capture", such as in wind energy, trees, or space travel), were manually excluded. In total, $57.5 \%$ of the remaining 167 papers presented results from basic technical research, while around $13 \%$ dealt with technical-economic valuation and reviews. Only $17 \%$ considered overall issues, such as DAC in the context of energy systems, political issues, or applications for $\mathrm{PtX}$, while $12.5 \%$ discussed DAC in the context of NETs (Figure 4).

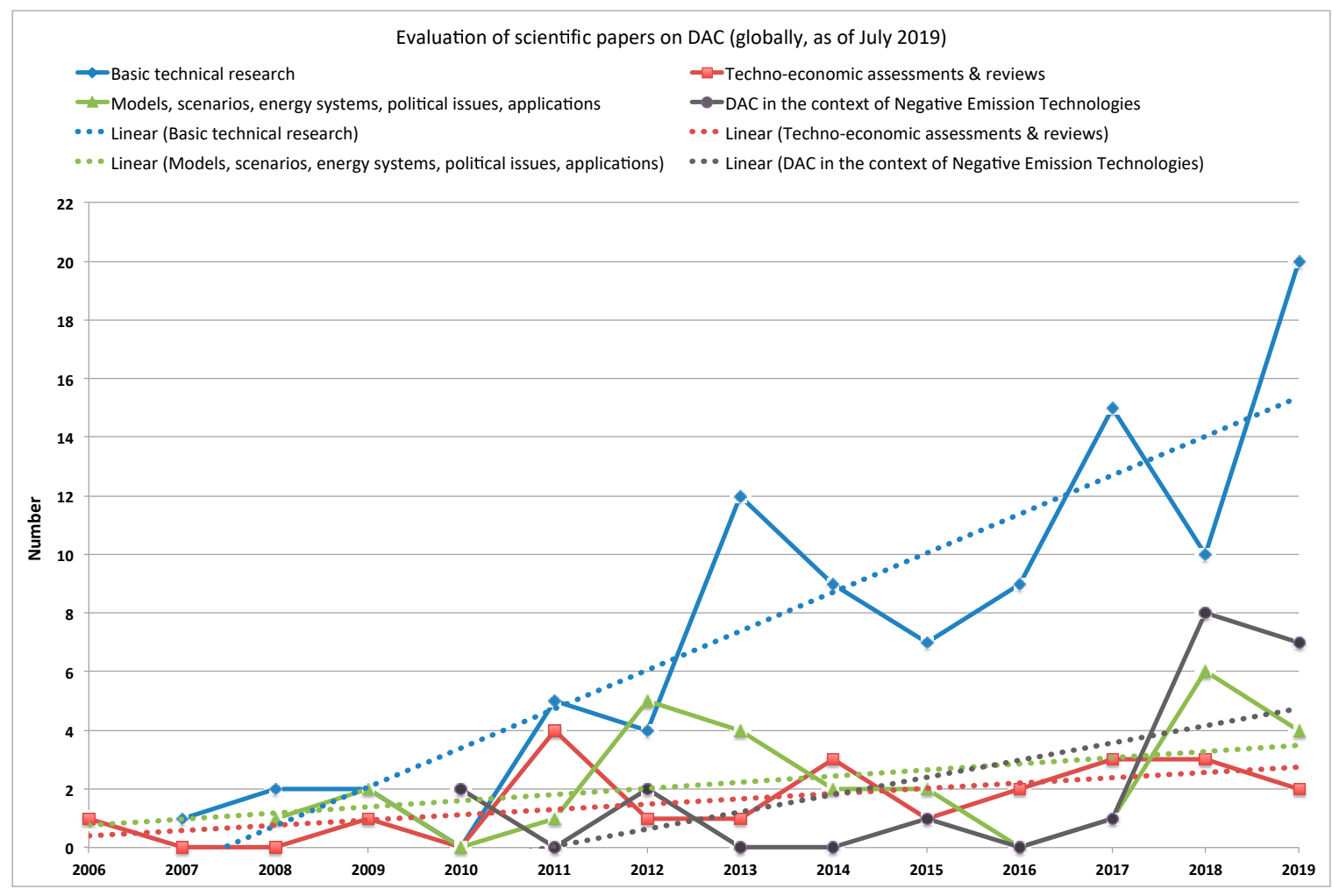

Figure 4. Evaluation of scientific articles on Direct Air Capture (DAC). 
The linear interpolation shows a steady increase, particularly in the case of basic technical research. One noteworthy aspect is the strong increase in both crosscutting issues and issues dealing with DAC in the context of NET from 2018 onwards, which can be expected to reach a similar magnitude in 2019. Only 11 out of the 167 papers (6.6\%) are from German authors (2 from 2019 and 9 from 2018), of which 3 papers include overarching topics and 6 papers are focused on DAC in the context of NET.

\subsection{Criterion 9: Societal Acceptance}

To the authors' knowledge, no studies or public discussions on the social acceptance of DAC systems are known at present. There have been critical reports and analyses on NET in general [47,64-67], but there are no acceptance studies available here either. With regard to the use of DACCS, synergies with the general issue of $\mathrm{CO}_{2}$ storage may be conceivable, but all corresponding acceptance studies refer to CCS for power plants and industry. For the case of Germany, one study demonstrated, for example, that the storage of $\mathrm{CO}_{2}$ from industrial plants had a somewhat higher acceptance than $\mathrm{CO}_{2}$ from power plants [68]. If it is a matter of achieving negative emissions or the release of climate-neutral $\mathrm{CO}_{2}$ for PtX processes, a completely different perception could emerge in society. Therefore, there is a considerable need for research on decisive factors regarding the acceptance of DAC and possible obstacles to its implementation, as well as to communication and participation processes with various groups of actors regarding DAC and its background.

\subsection{Criterion 10: Path Dependency}

Little or no path dependency is expected for using DAC within synthesis processes, as DAC facilities can be constructed on site with synthesis plants. In contrast, the risk of path dependency for the use of DAC as an NET is expected to be very high due to the extensive need for land, energy, and infrastructure. If DAC as an NET is to be implemented, it will be necessary to develop an overall concept that would be sustainable in the long term. Specifically, this would have to include not only the $\mathrm{CO}_{2}$ storage sites to be used and the infrastructure required, but also the provision of the energy required.

\subsection{Criterion 11: Dependence on Infrastructure}

Depending on the underlying concept, DAC facilities need thermal and/or electrical energy and thus rely on the commensurate infrastructure. Thermal options could include waste heat (according to the process), heat pumps, or high-temperature heat generation (e.g., natural gas, CSP); electricity can be provided either by public supply or via direct coupling with generation plants. Moreover, DAC facilities also require a significant amount of land (though this amount varies depending on the project), as well as a still partly unspecified need for water (see Section 3.4). Moreover, if on-site processing or storage of the captured $\mathrm{CO}_{2}$ in the case of DACCS is not an option, additional transport infrastructure (e.g., pipelines) would also be required. Ideally, plants for (renewable) power generation, water supply, and synthesis processes, as well as $\mathrm{CO}_{2}$ capture, would be located at the same site, so that only the synthesis products would have to be transported.

\subsection{Criterion 12: Systems Compatibility}

Given the respective scaling, the energy demands of DAC facilities in Germany would require adaptions in renewable energy generation. As Table 7 shows, for $\mathrm{PtL}$ and $\mathrm{PtC}$ purposes alone, satisfying the demand for climate-neutral $\mathrm{CO}_{2}$ (which was roughly and conservatively estimated above, see Figure 3) would require $121.5 \mathrm{TWh}_{\text {th }}$ of low-temperature heat and $40.5 \mathrm{TWh}_{\mathrm{el}}$ of electricity (based on Table 4). This calculation was done using the example of a Climeworks' DAC-36" system, as

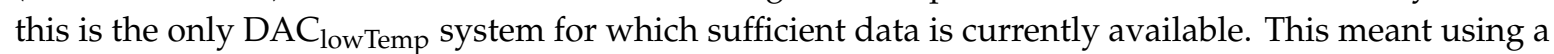
target heat consumption of $1.5 \mathrm{MWh}_{\mathrm{th}} / \mathrm{t} \mathrm{CO}_{2}$. While this level of heat consumption may be covered by waste heat from the necessary synthesis plants, the electricity demand (41 MWh) would represent an increase of $7.8 \%$ compared to the $527 \mathrm{TWh}_{\mathrm{el}}$ required in 2018 in Germany [69]. About twice as much 
heat and electricity would be needed if the estimated German share of negative emissions derived from the moderate scenario of Rogelj et al. [50] would have to be managed in Germany. In this case, additional heat sources would have to be taken into account. The feedback loops from the additional load on the entire energy system, including its spatial distribution, should therefore be analyzed in advance.

Table 7. Sample estimation of the use of land and energy for Direct Air Capture (DAC) plants to provide $\mathrm{CO}_{2}$ for both Power-to-Liquids (PtL) and Power-to-Chemicals (PtC) in Germany and as a possible German share of negative emissions in the year 2050 (own calculation; plant parameters based on $[25,26])$.

\begin{tabular}{lccccc}
\hline Field of Application & $\mathbf{C O}_{\mathbf{2}}$ Removal & Plants & Land Use & \multicolumn{2}{c}{ Energy Demand } \\
\hline & Mt/year & Number & $\mathrm{km}^{2} /$ year & $\mathrm{TWh}_{\mathrm{th}} /$ year & $\mathrm{TWh}_{\mathrm{el}} /$ year \\
\hline Power-to-X & & & & \\
\hline $\begin{array}{l}\text { Power-to-Chemicals } \\
\text { Power-to-Liquids }\end{array}$ & 55 & 30,556 & 5.5 & 83 & 28 \\
\hline Subtotal & 26 & 14,444 & 2.6 & 39 & 13 \\
\hline $\begin{array}{l}\text { Negative emissions, } \\
\text { derived from [50] }\end{array}$ & 169 & 45,000 & 8.1 & 122 & 41 \\
\hline Total & 250 & 94,000 & 16.9 & 254 & 85 \\
\hline 1) & 139,000 & 25 & 376 & 126 \\
\hline
\end{tabular}

Land use is also a crucial parameter in a densely populated country such as Germany. Without taking into account the land consumption for electricity production, the sample DAC plants alone may require an area of $8.1 \mathrm{~km}^{2}$ in the case of $\mathrm{PtX}$ processes and $16.9 \mathrm{~km}^{2}$ for negative emissions (based on Table 5), which equals $0.9 \%$ and $1.8 \%$ of the area of Berlin, respectively. Since this estimate contains some uncertainties, these values should be considered an initial estimate. On the one hand, only the area of the respective individual plants was taken into account, while for combined plant, parks in practice areas between the rows of plant towers would also have to be added. On the other hand, a large part of the considered area is used for control technology, which in the case of individual plants (e.g., the "DAC-36"), accounts for around $60 \%$ of the total area, but would no longer be significant in the case of large plants [25].

Negative interdependence (i.e., competition) with short- and medium-term climate policy goals might arise, particularly for the use of DAC as an NET, because the prospect of drastically reducing emissions after 2050 might diminish the sense of urgency for active climate policy within the coming decades. As a consequence, additional emissions might accrue (overshooting) $[67,70]$.

\section{Discussion}

The previous sections indicate that the future role of Direct Air Capture will be affected by a variety of uncertainty factors. The technology is still in an early stage of development and has yet to prove its large-scale technical feasibility, as well as its economic viability. Currently, there is neither consensus within the literature itself, nor between literature and manufacturers, on the potential for technical efficiency, as well as cost decreases. Furthermore, comprehensive technology assessments (e.g., in regard to coupling with low- or high-temperature synthesis facilities), which would be necessary to fully evaluate the applications outlined above, are lacking. Moreover, additional applications are conceivable for DAC that have not been examined in this study, e.g., as part of power-to-gas for heating or as a strategy for dealing with an intermittent energy supply from renewables.

The literature under review shows that there is a particular need for technical research in the development of $\mathrm{CO}_{2}$ sorbents and processes for the clusters under consideration. Even though adsorption/desorption processes have proven to be the most promising with regard to applications for 
the electricity-based production of fuels and chemicals, since they can utilize the low-temperature heat of synthesis plants [11], other processes should also be further developed in the spirit of open-ended research. In the case of high-temperature DAC, this could be, for example, the use of renewable energies instead of natural gas, which could include unprecedented investigations of the coupling of DAC with CSP plants, thus leveraging both their high-temperature heat and the electricity generated.

Several authors have given an overview of specific technical research needs [14,71-73]. Processes already developed to market maturity must be prepared for large-scale use and mass production, for example. This requires the minimization of energy requirements, plant scaling and, in particular, process integration, so that they can be optimally used for the production of electricity-based products-both for fuels and basic chemicals. Carbon Engineering has performed theoretical calculations to understand how to achieve this process with as little risk as possible [23]. Minx et al. have pointed out that a sense of urgency about the upscaling and diffusion of NET and thus also DAC technologies has not emerged, either among scientists or policymakers. They argued that the period from 2030 to 2050 would be essential for the massive expansion of NET [9]. The Innovation for Cool Earth Forum (ICEF) has summarized the most important innovation steps required in a roadmap for the next 20 years [74].

In addition to detailed cost analyses, Minx et al. also pointed to the need for comprehensive life-cycle assessments to assess the various environmental impacts of these chemical-based processes [9]. Williamson noted, in particular, the lack of safety and environmental impact assessments for NET technologies, but determined that DAC could still be the most environmentally friendly of these [46].

In light of the uncertainties associated with NET in general and with DAC in particular, climate scientists have been calling for integrated assessments of these technologies. Along these lines, Smith et al. pointed out which driving and braking forces should be considered in the evaluation of NET, which would also be relevant for DAC to a large extent [13]. Fuss et al. have described four criteria for a major new transdisciplinary research agenda regarding the management of NET: technologies and their sustainability impacts; carbon cycle uncertainties; policy and technology mix regarding cost, risk, and timing; and institutional and policy challenges [67]. To a certain extent, these also play a role in the use of DAC for PtX processes. This would also include critically scrutinizing existing potential assessments for DAC and/or NET, making more detailed estimates of the possible need for DAC for PtX and for achieving negative emissions, and also analyzing possible alternative options and the measures that would have to be taken to implement them. Although these demand-side issues should be urgently considered, a detailed investigation by Nemet et al. noted that $83 \%$ of the scientific work on NET has been concerned with the supply side (59 percentage points of which are R\&D alone, supplemented by work on demonstrations and scaleup) [11]. DAC itself has an even larger share. This confirms our results regarding Criterion 8 , where we found around $68.5 \%$ of the articles dealing with technical research, illustrating an urgent need for studies on technology (impact) assessment.

Last but not least, systems-level analyses are needed to analyze the interaction between the various plants in Germany and abroad. On the one hand, this concerns the potential demand for power-based fuels and chemicals and the timelines in which they could replace fossil-based substances. On the other hand, questions of the geographic location of the individual process steps have to be answered-from the location of DAC plants for $\mathrm{CO}_{2}$ separation and $\mathrm{CO}_{2}$ transport to the location of synthesis plants and the supply of the required electricity, heat, and water.

Temporal development also plays an important role, as large point sources with fossil $\mathrm{CO}_{2}$ could be used at first, until infrastructure for the use of climate-neutral $\mathrm{CO}_{2}$ is built. In turn, completing DAC facilities for $\mathrm{PtX}$ processes would serve as a path toward a possible massive deployment of DAC for the sake of negative emissions. Land consumption also must play a central role in the analysis of these issues, especially in densely populated industrialized countries, such as Germany. Finally, further research questions concern the output of the required plants and the establishment of corresponding mass production. Only then would it be possible to make estimates for the expected domestic added value of German companies (Criterion 7). If, for example, $1 \%$ of global $\mathrm{CO}_{2}$ emissions ( $350 \mathrm{Mt} / \mathrm{year}$ ) 
were to be separated by DAC alone, this would require around 200,000 of Climeworks' DAC-36 plants (Table 7). For 50\% of global emissions, 10 million plants would be required, which in terms of plant volume, would correspond to almost $14.5 \%$ of one year of current global passenger car production. In order to prepare for such an enormous technology diffusion, several hundred NET facilities may have to be installed annually between 2030 and 2050 [9].

Nemet et al. have pointed out that "the thousands to millions of actors that potentially need to adopt these technologies for them to achieve planetary scale" should also be considered (e.g., with regard to research on public acceptance) [12]. All these questions of technology assessment raised here require interdisciplinary and transdisciplinary studies at an early stage to be prepared for possible developments.

\section{Conclusions}

The previous sections show that it is currently impossible to determine either the future role of DAC or the possible role of the German industry, based on the current level of knowledge. The results of this multi-dimensional evaluation justify the inclusion of research on DAC technology in the German energy research program:

- Although many DAC prototypes and demonstration facilities exist, several development and upscaling steps will be necessary to achieve a Technology Readiness Level of 9, related to a large-scale commercial use, within the next ten years. This means the need for further technological development in order to reduce costs from the current $\$ 600 / \mathrm{tCO}_{2}$ to less than $\$ 100 / \mathrm{tCO}_{2}$ and thereby reduce the consumption of energy, water, and land during operation;

- While the technical risk is assumed to be rather low, the economic R\&D risk is assessed as high;

- The evaluation of the R\&D landscape shows only a small contribution of Germany in an international comparison in terms of R\&D budgets (very low), scientific publications $(6.6 \%)$, and patents (0);

- A large market potential for the use of DAC, not only in Germany, but also worldwide, may be expected to make a major contribution to value creation, which could lead to the expansion of the leading position of German industry;

- Even though no explicit research on DAC has taken place in Germany so far, German companies from the chemical and mechanical engineering industries are well positioned to advance the research and development of DAC processes.

In view of the considerable importance that DAC could receive in the future considering climate protection requirements, the role of DAC is likely to increase significantly. There is therefore also a great need for research worldwide, both with regard to technical development and in particular with regard to the development of deployment strategies and roadmaps for setting up DAC.

Apart from the research needs described above, there are major uncertainties and challenges in this field of technology:

- On the one hand, estimates of market potential are very uncertain (both for PtX applications and even more for use as NET). At the moment, it is not possible to predict in which sectors PtX applications will be needed in the medium to long term, nor whether NET will be needed at all, and if so, what role DAC could play;

- On the other hand, the need to reach a carbon-neutral economy by 2050 does not leave much time for either long-term research or the deployment of DAC in the case that this technology would prove to be an important part of the transition in the energy, transport, and chemical sector;

- A potentially massive deployment leads to the question of building up sufficient production capacities so that they are available in time. As the above comparison with automobile production has shown, the sheer volume of systems alone is likely to be a considerable challenge. However, not only the production structures, but also the substantial demand for energy and land in densely populated countries, could become a considerable challenge; 
- Last but not least, the possible application of DAC technologies has not yet been discussed in politics or in public. In particular, both socio-political and community acceptance could be critical and delay possible implementation by years.

Having all these issues in mind, a strong research focus on integrated assessments and system-level analyses is recommended. This should be accompanied by technical research as outlined above, so that the technologies are ready for use when needed. Systems analytical studies could also provide valuable information for technology development in order to identify possible risks and problems during subsequent implementation at an early stage and allow them to be taken into account in the technology development process.

Author Contributions: Conceptualization, P.V. and A.S.; methodology, P.V.; validation, O.Z.; formal analysis, A.S. and P.V.; investigation, A.S.; writing — original draft preparation, A.S. and P.V.; writing—review and editing, P.V., A.S., and O.Z.; supervision, P.V.; project administration, P.V.; funding acquisition, P.V.

Funding: This research was funded by the German Federal Ministry for Economic Affairs and Energy (BMWi), grant number 03ET4036A-C.

Acknowledgments: We thank Matthew Rees and Teresa Gehrs (LinguaConnect) for proofreading the manuscript and the anonymous reviewers for their valuable comments and suggestions.

Conflicts of Interest: The authors declare no conflict of interest. The funder had no role in the design of the study; in the collection, analyses, or interpretation of data; in the writing of the manuscript; or in the decision to publish the results. 


\section{Appendix A}

Table A1. Overview and data of published Direct Air Capture (DAC) demonstration facilities, based on [22,24,26,29,33,37].

\begin{tabular}{|c|c|c|c|c|c|c|c|c|c|c|c|c|c|}
\hline \multirow[t]{2}{*}{$\begin{array}{l}\text { Type of } \\
\text { DAC }\end{array}$} & & $\begin{array}{l}\text { DAC highTemp } \\
\text { Absorption and }\end{array}$ & \multicolumn{11}{|c|}{ DAC $_{\text {lowTemp }}$ Adsorption and Desorption } \\
\hline & & $\begin{array}{c}\text { Carbon } \\
\text { Engineering }\end{array}$ & & & & Climew & orks & & & & Hydrocell & $\begin{array}{c}\text { Global } \\
\text { Thermostat }\end{array}$ & zsw \\
\hline \multirow[t]{4}{*}{$\begin{array}{l}\text { Details } \\
\text { demo } \\
\text { facility }\end{array}$} & Location & Squamish (Canada) & $\begin{array}{c}\text { Hinwil } \\
\text { (Switzerland) }\end{array}$ & $\begin{array}{l}\text { Rapperswil } \\
\text { (Switzerland) }\end{array}$ & $\begin{array}{c}\text { Hellisheiðð } \\
\text { (Iceland) CarbFix }\end{array}$ & $\begin{array}{l}\text { Troia (Italy) } \\
\text { EU project } \\
\text { STOREEGO }\end{array}$ & $\begin{array}{c}\text { Turin } \\
\text { (Italy) } \\
\text { EU } \\
\text { project } \\
\text { CELBION }\end{array}$ & Móstoles & $\begin{array}{l}\text { Rotterdam } \\
\text { Airport (The } \\
\text { Netherlands) }\end{array}$ & $\begin{array}{c}\text { Heroya } \\
\text { (Norway) }\end{array}$ & $\begin{array}{c}\text { VTT \& } \\
\text { LUT } \\
\text { (Finland) }\end{array}$ & $\begin{array}{l}\text { SRI International } \\
\text { Menlo Park (USA, } \\
\text { California) }\end{array}$ & $\begin{array}{c}\text { Stuttgart } \\
\text { (Germany) } \\
\text { BMBF funded } \\
\text { CORAL project }\end{array}$ \\
\hline & Type & demonstration & commercial & commercial & demonstration & pilot & pilot & demonstration & demonstration & commercial & pilot & $\begin{array}{c}\text { pilot \& } \\
\text { commercial } 1)\end{array}$ & pilot \\
\hline & Used for & $\begin{array}{l}\text { "Air-to-Fuels" (A2F) } \\
\text { (with Greyrock } \\
\text { Energy) }\end{array}$ & $\begin{array}{l}\text { Greenhouses } \\
\text { (with nursery) }\end{array}$ & PtG & $\begin{array}{c}\text { Mineralization } \\
\text { (with Reykjavik } \\
\text { Energy) }\end{array}$ & $\begin{array}{l}\text { PtG (with } \\
\text { DVGW) }\end{array}$ & $\mathrm{PtC}$ & $\begin{array}{c}\text { Sun to } \\
\text { kerosene }\end{array}$ & $\begin{array}{l}\text { Feasibility } \\
\text { Study } \\
\text { Kerosene (with } \\
\text { Sunfire et al.) }\end{array}$ & $\begin{array}{c}\text { From } 2020 \mathrm{PtL} \\
\text { (with Sunfire } \\
\text { et al.) }\end{array}$ & $\begin{array}{l}\text { PtL, later } \\
\text { PtC }\end{array}$ & & \\
\hline & $\begin{array}{l}\text { Energy } \\
\text { supply }\end{array}$ & natural gas & $\begin{array}{l}\text { waste heat } \\
\text { from MVA }\end{array}$ & $\begin{array}{l}\text { Methane } \\
\text { synthesis }\end{array}$ & geothermal energy & $\begin{array}{l}\text { methane } \\
\text { synthesis }\end{array}$ & & $\begin{array}{l}\text { Fischer-Tropsch } \\
\text { synthesis }\end{array}$ & $\begin{array}{l}\text { Blue Crude } \\
\text { synthesis }\end{array}$ & $\begin{array}{c}\text { Blue Crude } \\
\text { synthesis }\end{array}$ & $\begin{array}{l}\text { Probably } \\
\text { synthesis }\end{array}$ & & \\
\hline \multirow[t]{3}{*}{$\begin{array}{c}\mathrm{CO}_{2} \\
\text { capture }\end{array}$} & $\mathrm{t} / \mathrm{day}$ & 0.6 & $\begin{array}{c}2.46 \\
(\text { ("DAC-18") }\end{array}$ & - & 0.135 (“DAC-1”) & $\begin{array}{c}0.419 \\
(“ \mathrm{DAC}-3 ")\end{array}$ & 0.016 & - & - & - & 0.0038 & 2 (pilot) & 0.047 \\
\hline & t/year & 219 & 900 & - & 50 & 150 & 5.8 & - & - & 21,000 & 1.39 & 730 (pilot) & 0.017 \\
\hline & $\mathrm{t} /\left(\mathrm{a} \cdot \mathrm{m}^{2}\right)$ & - & 10 & - & - & 7.5 & - & - & - & - & - & 80 (pilot) & - \\
\hline $\begin{array}{c}\text { Fuel } \\
\text { production }\end{array}$ & t/year & 48 & - & - & - & - & - & & 292 & 8000 & 22 & - & - \\
\hline $\begin{array}{c}\text { Scientific } \\
\text { papers }\end{array}$ & & {$[23,59,75]$} & & & & {$[76-8$} & & & & & [34] & [84-86] & \\
\hline
\end{tabular}

PtC = Power-to-Chemicals; PtG = Power-to-Gas; PtL = Power-to-Liquids; MVA = Müllverbrennungsanlage (incinerator), n.a. = no paper given. ${ }^{1)}$ No data available for commercial plants. 


\section{References}

1. IPCC. IPCC Climate Change 2014: Synthesis Report. Contribution of Working Groups I, II and III to the Fifth Assessment Report of the Intergovernmental Panel on Climate Change; IPCC: Geneva, Switzerland, 2014.

2. UNFCC. The Paris Agreement. United Nations Framework Convention on Climate Change; UN Climate Change Annual Report; UNFCC: Bonn, Germany, 2018.

3. IPCC. Summary for policymakers. In Global Warming of $1.5^{\circ} \mathrm{C}$; An IPCC Special Report on the impacts of global warming of $1.5^{\circ} \mathrm{C}$ above pre-industrial levels and related global greenhouse gas emission pathways, in the context of strengthening the global response to the threat of climate change, sustainable development, and efforts to eradicate poverty; IPCC: Geneva, Switzerland, 2018; p. 32.

4. BMWi. Innovationen für die Energiewende. 7. Energieforschungsprogramm der Bundesregierung; Bundesministerium für Wirtschaft und Energie: Berlin, Germany, 2018.

5. Wuppertal Institut. Technologies for the Energy Transition ("Energiewende"): Status and Perspectives, Innovation and Market Potential-A Comparative Multi-Criteria Technology Analysis and Assessment; Wuppertal Institut: Wuppertal, Germany; ISI: Karlsruhe, Germany; IZES: Saarbrücken, Germany, 2018.

6. Teske, S.; Sawyer, S.; Schäfer, O.; Pregger, T.; Simon, S.; Naegler, T. Energy [R]evolution-A Sustainable World Energy Outlook 2015. 100\% Renewable Energy for all; Greenpeace International: Amsterdam, The Netherlands; Global Wind Energy Council: Brussels, Belgium; SolarPowerEurope: Brussels, Belgium, 2015.

7. Grubler, A.; Wilson, C.; Bento, N.; Boza-Kiss, B.; Krey, V.; McCollum, D.L.; Rao, N.D.; Riahi, K.; Rogelj, J.; Stercke, S.D.; et al. A low energy demand scenario for meeting the $1.5^{\circ} \mathrm{C}$ target and sustainable development goals without negative emission technologies. Nat. Energy 2018, 3, 515. [CrossRef]

8. Moriarty, P.; Honnery, D. Ecosystem maintenance energy and the need for a green EROI. Energy Policy 2019, 131, 229-234. [CrossRef]

9. Minx, J.C.; Lamb, W.F.; Callaghan, M.W.; Fuss, S.; Hilaire, J.; Creutzig, F.; Amann, T.; Beringer, T.; Garcia, W. de O.; Hartmann, J.; et al. Negative emissions-Part 1: Research landscape and synthesis. Environ. Res. Lett. 2018, 13, 063001. [CrossRef]

10. Fuss, S.; Lamb, W.F.; Callaghan, M.W.; Hilaire, J.; Creutzig, F.; Amann, T.; Beringer, T.; de Oliveira Garcia, W.; Hartmann, J.; Khanna, T.; et al. Negative emissions-Part 2: Costs, potentials and side effects. Environ. Res. Lett. 2018, 13, 063002. [CrossRef]

11. Fasihi, M.; Efimova, O.; Breyer, C. Techno-economic assessment of $\mathrm{CO}_{2}$ direct air capture plants. J. Clean. Prod. 2019, 224, 957-980. [CrossRef]

12. Nemet, G.F.; Callaghan, M.W.; Creutzig, F.; Fuss, S.; Hartmann, J.; Hilaire, J.; Lamb, W.F.; Minx, J.C.; Rogers, S.; Smith, P. Negative emissions-Part 3: Innovation and upscaling. Environ. Res. Lett. 2018, 13, 063003. [CrossRef]

13. Smith, P.; Davis, S.J.; Creutzig, F.; Fuss, S.; Minx, J.; Gabrielle, B.; Kato, E.; Jackson, R.B.; Cowie, A.; Kriegler, E.; et al. Biophysical and economic limits to negative $\mathrm{CO}_{2}$ emissions. Nat. Clim. Chang. 2016, 6, 42-50. [CrossRef]

14. Goeppert, A.; Czaun, M.; Surya Prakash, G.K.; Olah, G.A. Air as the renewable carbon source of the future: An overview of $\mathrm{CO}_{2}$ capture from the atmosphere. Energy Environ. Sci. 2012, 5, 7833. [CrossRef]

15. Lackner, K.S. Capture of carbon dioxide from ambient air. Eur. Phys. J. Spec. Top. 2009, 176, 93-106. [CrossRef]

16. Specht, M.; Bandi, A.; Elser, M.; Staiss, F. Comparison of $\mathrm{CO}_{2}$ sources for the synthesis of renewable methanol. In Studies in Surface Science and Catalysis; Elsevier: Amsterdam, The Netherlands, 1998; Volume 114, pp. 363-366. ISBN 978-0-444-82574-2.

17. Eisaman, M.D.; Alvarado, L.; Larner, D.; Wang, P.; Garg, B.; Littau, K.A. $\mathrm{CO}_{2}$ separation using bipolar membrane electrodialysis. Energy Environ. Sci. 2011, 4, 1319-1328. [CrossRef]

18. Baciocchi, R.; Storti, G.; Mazzotti, M. Process design and energy requirements for the capture of carbon dioxide from air. Chem. Eng. Process. Process Intensif. 2006, 45, 1047-1058. [CrossRef]

19. Socolow, R.; Desmond, M.; Aines, R.; Blackstock, J.; Bolland, O.; Kaarsberg, T.; Lewis, N.; Mazzotti, M.; Pfeffer, A.; Sawyer, K.; et al. Direct Air Capture of $\mathrm{CO}_{2}$ with Chemicals. A Technology Assessment for the APS Panel on Public Affairs; The American Physical Society: College Park, MD, USA, 2011.

20. Mazotti, M.; Abanades, J.; Allam, R.; Lackner, K.; Meunier, F.; Rubin, E.; Sanchez, J.; Yogo, K.; Zevenhoven, R. Mineral carbonation and industrial uses of carbon dioxide. In IPCC Special Report on Carbon dioxide Capture and Storage; IPCC: Geneva, Switzerland, 2005. 
21. Zeman, F. Reducing the Cost of Ca-Based Direct Air Capture of $\mathrm{CO}_{2}$. Environ. Sci. Technol. 2014, 48, 11730-11735. [CrossRef]

22. Carbon Engineering $\mathrm{CO}_{2}$ Capture and the Synthesis of Clean Transportation Fuels. Available online: https://carbonengineering.com/ (accessed on 25 July 2019).

23. Keith, D.W.; Holmes, G.; St. Angelo, D.; Heidel, K. A Process for Capturing $\mathrm{CO}_{2}$ from the Atmosphere. Joule 2018, 2, 1573-1594. [CrossRef]

24. SUN-to-LIQUID Solar Fuel Breakthrough. SUN-to-LIQUID Produces Solar Kerosene from Sunlight, Water and $\mathrm{CO}_{2}$. Available online: https://www.sun-to-liquid.eu/page/media_items/sun-to-liquid-project-pressrelease14.php (accessed on 25 July 2019).

25. Climeworks Expert interview by Peter Viebahn with Climeworks on 12 March 2018. Wuppertal 2018.

26. Climeworks Capturing $\mathrm{CO}_{2}$ from Air. Available online: https://www.climeworks.com/ (accessed on 25 July 2019).

27. Reykjavik Energy the CarbFix Project. Available online: https://www.carbfix.com/carbfix-2011-2014 (accessed on 27 July 2019).

28. Climeworks Become a Climeworks Pioneer-Capture and Turn Unavoidable $\mathrm{CO}_{2}$ Emissions into Stone. See how it works! Available online: https://climeworks.shop (accessed on 9 July 2019).

29. Sunfire First Commercial Plant for the Production of Blue Crude Planned in Norway. Available online: https://www.sunfire.de/en/company/news/detail/first-commercial-plant-for-the-production-of-bluecrude-planned-in-norway (accessed on 25 July 2019).

30. EDL. Renewable Jet Fuel from Air. Available online: http://www.edl.poerner.de/en/news-edl/edlpressemeldung/news/erneuerbarer-flugtreibstoff-aus-luft/ (accessed on 25 July 2019).

31. Global Thermostat. A Carbon Negative Solution. Available online: https://globalthermostat.com/ (accessed on 25 July 2019).

32. KIT. Power-to-Liquid: 200 Liter Sprit aus Solarstrom und dem Kohlenstoffdioxid der Umgebungsluft; Karlsruher Institut für Technologie: Karlsruhe, Germany, 2017.

33. VTT; LUT. The Soletair Project; VTT Technical Research Centre of Finland: Espoo, Finland; Lappeenranta University of Technology LUT: Lappeenranta, Finland, 2018.

34. Vázquez, F.V.; Koponen, J.; Ruuskanen, V.; Bajamundi, C.; Kosonen, A.; Simell, P.; Ahola, J.; Frilund, C.; Elfving, J.; Reinikainen, M.; et al. Power-to-X technology using renewable electricity and carbon dioxide from ambient air: SOLETAIR proof-of-concept and improved process concept. J. $\mathrm{Co}_{2}$ Util. 2018, 28, 235-246. [CrossRef]

35. Hydrocell Direct Air Capture (DAC) Appliances. Available online: https://hydrocell.fi/en/air-cleanerscarbon-dioxide-filters-and-dac-appliances/dac-appliances/ (accessed on 23 July 2019).

36. McLaren, D. Geoengineering our Climate? Capturing the Imagination: Prospects for Direct Air Capture as a Climate Measure (Case Study); A Working Paper Series on the Ethics, Politics and Governance of Climate Energineering; Earthscan: Routledge, UK, 2014.

37. ZSW. More Efficient Direct Air Capture of $\mathrm{CO}_{2}$ for Regenerative Fuels. Centre for Solar Energy and Hydrogen Research Baden-Württemberg (ZSW). Available online: https://www.zsw-bw.de/en/newsroom/news/newsdetail/news/detail/News/more-efficient-direct-air-capture-of-co2-for-regenerative-fuels.html (accessed on 23 July 2019).

38. BMWi. Forschung für Eine Umweltschonende, Zuverlässige und Bezahlbare Energieversorgung. Das 6. Energieforschungsprogramm der Bundesregierung; Bundesministerium für Wirtschaft und Energie: Berlin, Germany, 2011.

39. PTJ. Technologiereifegrad—Definition und Methoden zur Einschätzung. Bereitgestellt für das Forschungsprojekt Technologien für die Energiewende; Projektträger Jülich: Jülich, Germany, 2017.

40. Arnold, K.; Kobiela, G.; Pastowski, A. Technologiebericht 4.3 Power-to-liquids/-chemicals. In Wuppertal Institut; ISI; IZES (Eds) Technologien für die Energiewende. Teilbericht 2 an das Bundesministerium für Wirtschaft und Energie (BMWi); Wuppertal Institut: Wuppertal, Germany; ISI: Karlsruhe, Germany; IZES: Saarbrücken, Germany, 2018; pp. 145-222.

41. Öko-Institut; Fraunhofer ISI. Klimaschutzszenario 2050-2. Endbericht—Studie im Auftrag des Bundesministeriums für Umwelt, Naturschutz, Bau und Reaktorsicherheit; Öko-Institut e.V.: Berlin, Germany; Frauenhofer ISI: Karlsruhe, Germany, 2015. 
42. GlobalData Energy US and China Driving Global Ethylene Capacity to Record 208 Million Tons per Year by 2017. Available online: http://energy.globaldata.com/media-center/press-releases/oil-and-gas/us-and-chinadriving-global-ethylene-capacity-to-record-208-million-tons-per-year-by-2017-says-globaldata (accessed on 28 April 2017).

43. Chemicals-Technology. Worldwide demand for propylene to rise to 130 million Tonnes by 2023. Available online: http://www.chemicals-technology.com/news/newsworldwide-demand-for-propylene-to-rise-to-130million-tonnes-by-2023-says-ihs-4356137 (accessed on 28 April 2017).

44. IEA-International Energy Agency. Technology Roadmap Energy and GHG Reductions in the Chemical Industry via Catalytic Processes; Corlet: Paris, France, 2013.

45. IEA-International Energy Agency. World Energy Outlook 2016; International Energy Agency: Paris, France, 2016; ISBN 978-92-64-26494-6.

46. Williamson, P. Emissions reduction: Scrutinize $\mathrm{CO}_{2}$ removal methods. Nat. News 2016, 530, 153. [CrossRef]

47. Heck, V.; Gerten, D.; Lucht, W.; Popp, A. Biomass-based negative emissions difficult to reconcile with planetary boundaries. Nat. Clim. Chang. 2018, 8, 151-155. [CrossRef]

48. Chen, C.; Tavoni, M. Direct air capture of $\mathrm{CO}_{2}$ and climate stabilization: A model based assessment. Clim. Chang. 2013, 118, 59-72. [CrossRef]

49. Marcucci, A.; Kypreos, S.; Panos, E. The road to achieving the long-term Paris targets: Energy transition and the role of direct air capture. Clim. Chang. 2017, 144, 181-193. [CrossRef]

50. Rogelj, J.; Luderer, G.; Pietzcker, R.C.; Kriegler, E.; Schaeffer, M.; Krey, V.; Riahi, K. Energy system transformations for limiting end-of-century warming to below $1.5^{\circ} \mathrm{C}$. Nat. Clim. Chang. 2015, 5, 519-527. [CrossRef]

51. Wüstenhagen, R.; Wolsink, M.; Bürer, M.J. Social acceptance of renewable energy innovation: An introduction to the concept. Energy Policy 2007, 35, 2683-2691. [CrossRef]

52. Gates, B. 10 Breakthrough Technologies 2019. Available online: https://www.technologyreview.com/ magazine/2019/03/ (accessed on 23 July 2019).

53. Evans, S. The Swiss Company Hoping to Capture 1\% of Global $\mathrm{CO}_{2}$ Emissions by 2025; CarbonBrief. Available online: https://www.carbonbrief.org/swiss-company-hoping-capture-1-global-co2-emissions-2025 (accessed on 22 June 2017).

54. Napp, T.; Hills, T.; Soltani, S.M.; Bosch, J.; Mazur, C. A Survey of Key Technological Innovations for the Low-Carbon Economy; Imperial College London: London, UK, 2017.

55. Lomax, G.; Lenton, T.M.; Adeosun, A.; Workman, M. Investing in negative emissions. Nat. Clim. Chang. 2015, 5, 498-500. [CrossRef]

56. The Royal Society. Royal Academy of Engineering Greenhouse Gas Removal. Available online: https: //royalsociety.org/topics-policy/projects/greenhouse-gas-removal/ (accessed on 23 July 2019).

57. Schmidt, P.; Weindorf, W.; Roth, A.; Batteiger, V.; Riegel, F. Power-to-Liquids. Potentials and Perspectives for the Future Supply of Renewable Aviation Fuel; Background; Umweltbundesamt: Dessau-Roßlau, Germany, 2016.

58. Schmidt, P.R.; Zittel, W.; Weindorf, W.; Raksha, T. Renewables in Transport 2050. Empowering a Sustainable Mobility Future with Zero Emission Fuels from Renewable Electricity. Kraftstoffstudie II. Final Report; Forschungsvereinigung Verbrennungskraftmaschinen e.V.: Frankfurt, Germany, 2016; pp. 5-97.

59. Holmes, G.; Keith, D.W. An air-liquid contactor for large-scale capture of $\mathrm{CO}_{2}$ from air. Philos. Trans. R. Soc. Math. Phys. Eng. Sci. 2012, 370, 4380-4403. [CrossRef]

60. Stolaroff, J.K.; Keith, D.W.; Lowry, G.V. Carbon dioxide capture from atmospheric air using sodium hydroxide spray. Environ. Sci. Technol. 2008, 42, 2728-2735. [CrossRef]

61. Kintisch, E. Can Sucking $\mathrm{CO}_{2}$ Out of the Atmosphere Really Work? Available online: https: //www.technologyreview.com/s/531346/can-sucking-co2-out-of-the-atmosphere-really-work/ (accessed on 25 July 2019).

62. House, K.Z.; Baclig, A.C.; Ranjan, M.; van Nierop, E.A.; Wilcox, J.; Herzog, H.J. Economic and energetic analysis of capturing $\mathrm{CO}_{2}$ from ambient air. Proc. Natl. Acad. Sci. USA 2011, 108, 20428-20433. [CrossRef]

63. Samadi, S. The experience curve theory and its application in the field of electricity generation technologies-A literature review. Renew. Sustain. Energy Rev. 2018, 82, 2346-2364. [CrossRef]

64. European Academies' Science Advisory Council (EASAC). Negative Emission Technologies: What Role in Meeting Paris Agreement Targets; German National Academy of Sciences: Halle, Germany, 2018.

65. Marchant, J.; Spinelli, V.; Hoseini, M. Paradise Lost? Developing Solutions to Iran's Environmental Crisis; Heinrich Böll Foundation: Berlin, Germany; Small Media: London, UK, 2017. 
66. Anderson, K.; Peters, G. The trouble with negative emissions. Science 2016, 354, 182-183. [CrossRef]

67. Fuss, S.; Canadell, J.G.; Peters, G.P.; Tavoni, M.; Andrew, R.M.; Ciais, P.; Jackson, R.B.; Jones, C.D.; Kraxner, F.; Nakicenovic, N.; et al. Betting on negative emissions. Nat. Clim. Chang. 2014, 4, 850-853. [CrossRef]

68. Dütschke, E.; Wohlfarth, K.; Höller, S.; Viebahn, P.; Schumann, D.; Pietzner, K. Differences in the public perception of CCS in Germany depending on $\mathrm{CO}_{2}$ source, transport option and storage location. Int. J. Greenh. Gas Control 2016, 53, 149-159. [CrossRef]

69. Umweltbundesamt (UBA). Stromverbrauch. Available online: https://www.umweltbundesamt.de/daten/ energie/stromverbrauch (accessed on 23 July 2019).

70. Shue, H. Climate dreaming: Negative emissions, risk transfer, and irreversibility. J. Hum. Rights Environ. 2017, 8, 203-216. [CrossRef]

71. Broehm, M.; Strefler, J.; Bauer, N. Techno-Economic Review of Direct Air Capture Systems for Large Scale Mitigation of Atmospheric $\mathrm{CO}_{2}$. SSRN Electron. J. 2015. [CrossRef]

72. Koytsoumpa, E.I.; Bergins, C.; Kakaras, E. The $\mathrm{CO}_{2}$ economy: Review of $\mathrm{CO}_{2}$ capture and reuse technologies. J. Supercrit. Fluids 2018, 132, 3-16. [CrossRef]

73. Sanz-Pérez, E.S.; Murdock, C.R.; Didas, S.A.; Jones, C.W. Direct Capture of $\mathrm{CO}_{2}$ from Ambient Air. Chem. Rev. 2016, 116, 11840-11876. [CrossRef]

74. ICEF. Innovation for Cool Earth Forum 2018 Roadmap: Direct Air Capture of Carbon Dioxide. Available online: https://www.icef-forum.org/roadmap/ (accessed on 23 July 2019).

75. Holmes, G.; Nold, K.; Walsh, T.; Heidel, K.; Henderson, M.A.; Ritchie, J.; Klavins, P.; Singh, A.; Keith, D.W. Outdoor Prototype Results for Direct Atmospheric Capture of Carbon Dioxide. Energy Procedia 2013, 37, 6079-6095. [CrossRef]

76. Wurzbacher, J.A.; Gebald, C.; Brunner, S.; Steinfeld, A. Heat and mass transfer of temperature-vacuum swing desorption for $\mathrm{CO}_{2}$ capture from air. Chem. Eng. J. 2016, 283, 1329-1338. [CrossRef]

77. Wurzbacher, J.A.; Gebald, C.; Steinfeld, A. Separation of $\mathrm{CO}_{2}$ from air by temperature-vacuum swing adsorption using diamine-functionalized silica gel. Energy Environ. Sci. 2011, 4, 3584. [CrossRef]

78. Wurzbacher, J.A.; Gebald, C.; Piatkowski, N.; Steinfeld, A. Concurrent Separation of $\mathrm{CO}_{2}$ and $\mathrm{H}_{2} \mathrm{O}$ from Air by a Temperature-Vacuum Swing Adsorption/Desorption Cycle. Environ. Sci. Technol. 2012, 46, 9191-9198. [CrossRef]

79. Gebald, C.; Wurzbacher, J.A.; Tingaut, P.; Zimmermann, T.; Steinfeld, A. Amine-Based Nanofibrillated Cellulose as Adsorbent for $\mathrm{CO}_{2}$ Capture from Air. Environ. Sci. Technol. 2011, 45, 9101-9108. [CrossRef]

80. Gebald, C.; Wurzbacher, J.A.; Tingaut, P.; Steinfeld, A. Stability of Amine-Functionalized Cellulose during Temperature-Vacuum-Swing Cycling for $\mathrm{CO}_{2}$ Capture from Air. Environ. Sci. Technol. 2013, 47, 10063-10070. [CrossRef]

81. Gebald, C.; Wurzbacher, J.A.; Borgschulte, A.; Zimmermann, T.; Steinfeld, A. Single-component and binary $\mathrm{CO}_{2}$ and $\mathrm{H}_{2} \mathrm{O}$ adsorption of amine-functionalized cellulose. Environ. Sci. Technol. 2014, 48, 2497-2504. [CrossRef]

82. Nikulshina, V.; Gebald, C.; Steinfeld, A. $\mathrm{CO}_{2}$ capture from atmospheric air via consecutive CaO-carbonation and $\mathrm{CaCO}_{3}$-calcination cycles in a fluidized-bed solar reactor. Chem. Eng. J. 2009, 146, 244-248. [CrossRef]

83. Gutknecht, V.; Snæbjörnsdóttir, S.Ó.; Sigfússon, B.; Aradóttir, E.S.; Charles, L. Creating a carbon dioxide removal solution by combining rapid mineralization of $\mathrm{CO}_{2}$ with direct air capture. Energy Procedia 2018, 146, 129-134. [CrossRef]

84. Eisenberger, P.M. Chaos control: Climate stabilization by closing the global carbon cycle. In The Economics of the Global Environment; Chichilnisky, G., Rezai, A., Eds.; Springer International Publishing: Cham, Switzerland, 2016; Volume 29, pp. 367-388. ISBN 978-3-319-31941-4.

85. Eisenberger, P.M.; Cohen, R.W.; Chichilnisky, G.; Eisenberger, N.M.; Chance, R.R.; Jones, C.W. Global warming and carbon-negative technology: Prospects for a lower-cost Route to a lower-risk atmosphere. Energy Environ. 2009, 20, 973-984. [CrossRef]

86. Realff, M.J.; Eisenberger, P. Flawed analysis of the possibility of air capture. Proc. Natl. Acad. Sci. USA 2012, 109, E1589. [CrossRef]

(C) 2019 by the authors. Licensee MDPI, Basel, Switzerland. This article is an open access article distributed under the terms and conditions of the Creative Commons Attribution (CC BY) license (http://creativecommons.org/licenses/by/4.0/). 